\title{
Improvement of the Early-Age Compressive Strength, Water Permeability, and Sulfuric Acid Resistance of Scoria-Based Mortars/Concrete Using Limestone Filler
}

\author{
Aref Al-Swaidani, ${ }^{1}$ Andraos Soud, ${ }^{2}$ and Amina Hammami ${ }^{2}$ \\ ${ }^{1}$ Faculty of Architectural Engineering, Arab International University, Damascus, Syria \\ ${ }^{2}$ Transportation Engineering Department, Faculty of Civil Engineering, Damascus University, Damascus, Syria \\ Correspondence should be addressed to Aref Al-Swaidani; aydlswaidani@yahoo.fr
}

Received 9 June 2017; Accepted 26 September 2017; Published 8 November 2017

Academic Editor: Tung-Chai Ling

Copyright (C) 2017 Aref Al-Swaidani et al. This is an open access article distributed under the Creative Commons Attribution License, which permits unrestricted use, distribution, and reproduction in any medium, provided the original work is properly cited.

\begin{abstract}
Natural pozzolan is being widely used as cement replacement. Despite the economic, ecological, and technical benefits of its adding, it is often associated with shortcomings such as the need of moist-curing for longer time and a lower early strength. This study is an attempt to investigate the effect of adding limestone filler on the compressive strength and durability of mortars/concrete containing scoria. Sixteen types of binders with different replacement levels of scoria $(0,10,20$, and $30 \%)$ and limestone $(0,5,10$, and $15 \%)$ were prepared. The development of the compressive strength of mortar/concrete specimens was investigated after 2, 7, 28, and 90 days' curing. In addition, the acid resistance of the 28 days' cured mortars was evaluated after 90 days' exposure to $5 \% \mathrm{H}_{2} \mathrm{SO}_{4}$. Concrete permeability was also evaluated after $2,7,28$, and 90 days' curing. Test results revealed that there was an increase in the early-age compressive strength and a decrease in water penetration depths with adding limestone filler. Contrary to expectation, the best acid resistance to $5 \% \mathrm{H}_{2} \mathrm{SO}_{4}$ solution was noted in the mortars containing $15 \%$ limestone. Based on the results obtained, an empirical equation was derived to predict the compressive strength of mortars.
\end{abstract}

\section{Introduction}

Natural pozzolan is being widely used as cement replacement due to its ecological, economic, and performance-related advantageous properties [1-6]. However, its use caused longer setting times and lower early strengths compared with plain Portland cement $[7,8]$. To overcome the disadvantages of low early strengths of binders containing natural pozzolans, adding limestone filler could be a solution.

During the last decade, limestone has proven to be an effective partial replacement for OPC. The effect of limestone filler on OPC is twofold. Replacing part of the OPC with limestone filler will provide additional surface for precipitation of hydration products, thereby promoting the earlyage hydration of the OPC $[9,10]$. Besides the aforesaid physical effect or what is called the filler effect, there is also a chemical effect: the calcium carbonate of the limestone filler can interact with the aluminate hydrates formed by OPC hydration $[9,11,12]$. Calcium monosulfoaluminate hydrate is unstable in the presence of calcium carbonate, and instead calcium mono- and hemicarboaluminate hydrate will form. This leads to the stabilization of the ettringite and will result in an increase in the total volume of the hydration products $[9$, 12,13 , which potentially might result in a decrease in porosity and thus an increase in strength. The effect of this chemical interaction in an OPC-limestone system is, however, not so pronounced due to the limited aluminate content in the anhydrous clinker. In OPC the limestone filler is therefore often considered inert. The chemical interaction between calcium aluminate hydrates $(\mathrm{CAH})$ and calcium carbonate (CC) might therefore be of greater importance in binders containing supplementary cementitious materials of significant contents of aluminates such as fly ash, metakaolin, and natural pozzolan. The $\mathrm{CAH}$ formed during the pozzolanic reaction react with the $\mathrm{CC}$ of the limestone filler and form calcium carboaluminate hydrates [9]. 
Portland cement concrete is vulnerable to acid erosion because of its high content of alkaline hydrates. In recent years, Portland cement concrete often incorporates pozzolans due to various benefits. One of these important benefits is the higher acidic resistance due to the dense microstructure and reduced calcium hydroxide, $\mathrm{Ca}(\mathrm{OH})_{2}$ [1]. However, the main composition of limestone filler is calcium carbonate, $\mathrm{CaCO}_{3}$, which easily suffers from acid attack.

Syria is rich in both limestone and volcanic scoria with estimated reserves of about 12 billion cubic meters and one billion tonnes, respectively $[14,15]$. Although there are numerous studies on using natural pozzolan and limestone filler as cement replacement, very little works have been carried out in the past to investigate the influence of adding limestone filler on the mechanical and durability properties of volcanic scoria-based binder mortar/concrete. In addition, literature did not cover the wide area of durability and did not give answers in many areas regarding the growing use of limestone filler-volcanic scoria-OPC system.

The objective of this paper is to investigate the influence of adding limestone filler on some properties of mortars/concrete containing volcanic scoria-based binders. Compressive strength, acid resistance, and water permeability have particularly been investigated. Sixteen binders with different replacement levels of volcanic scoria $(0,10,20$, and $30 \%)$ and limestone filler $(0,5,10$, and $15 \%)$ have been produced for this investigation.

The study is of particular importance for the following points:

(i) Studying the strength development of both mortars and concrete with the same $(\mathrm{w} / \mathrm{b})$ ratio was not probably tackled before. Therefore, to predict the compressive strength of concrete depending on the mortar results could be considered a good approach.

(ii) Replacement of OPC by volcanic scoria and limestone filler could significantly minimize $\mathrm{CO} 2$ released into atmosphere and save energy.

(iii) This study is the first of its kind in Syria. However, it is not limited to the country. It can be applied to other countries of similar geology, for example, Harrat Al-Shaam, a volcanic field which covers a total area of some $45,000 \mathrm{~km}^{2}$; about $15,000 \mathrm{~km}^{2}$ is located in the country, Figure 1 . The rest covers parts of Jordan and KSA.

(iv) As our country begins preparations for the huge reconstruction after the war comes to its end, the encouraging results can be considered a motivation of other studies, such as using these local supplementary cementing materials in enhancement of properties of recycled concrete which are expected to be inevitable building material during the postwar reconstruction in Syria.

It is worth mentioning that, in previously published papers on studying Syrian volcanic scoria as cement replacement, the scoria was quarried from Dirat-at-Tulul (it is currently out of the governmental control) and ground with all other binder components (i.e., clinker and gypsum) together (i.e., intergrinding) into a specific fineness $[1,16,17]$. However, in the present study, another supplementary cementitious material (i.e., limestone filler) was added as cement replacement. In addition, the used volcanic scoria was quarried from Tal Shihan (it is under control of the government), which is about $75 \mathrm{~km}$ far from the Dirat-at-Tulul quarry. This was clearly seen from the varying chemical and mineralogical compositions. All binder components (i.e., scoria, limestone, and OPC) were separately ground into specific levels of fineness. This grinding process was adopted because it ensures achieving the required level of supplementary cementitious materials fineness. In addition, more attention was paid to investigating the effects of adding limestone filler to the scoria-based cement on the physical, mechanical, and some durability-related properties of paste/mortar/concrete. The microstructure of ternary binder pastes was investigated thoroughly, as well. Furthermore, prediction of mechanical strength of mortars/concrete containing both volcanic scoria and limestone filler can be of considerable benefit. Despite the large number of studies which dealt with the natural pozzolan and limestone filler containing concrete, there is a lack of such a prediction.

\section{Materials and Methods}

2.1. Volcanic Scoria. Volcanic scoria (VS) used in the experiments was collected from a Tal Shihan' quarry, $70 \mathrm{~km}$ southeast of Damascus, as shown in Figure 1. Mineralogical and petrographic properties of VS were identified under the polarizing microscope by using their thin sections (Figure 2(a)) and X-ray powder diffraction (XRD) analysis of the powdered bulk samples was carried out (Figure 2(b)). The petrographic examination showed that VS consisted of amorphous glassy ground mass, vesicles, plagioclase, olivine, and pyroxene. The chemical analysis of VS used in the study is summarized in Table 1 . This analysis was carried out by means of wet chemical analysis specified in EN 196-2(1989).

2.2. Limestone. Limestone was quarried from Hama governance, $210 \mathrm{~km}$ north of Damascus. Chemical and some physical properties of limestone are presented in Table 1. Its total organic carbon (TOC) and clay contents have been determined in accordance with EN 13639 and EN 933-9, respectively. Limestone sample has been dried and ground to the required size. SEM of the limestone filler (LF) with EDX analysis were shown in Figure 3.

2.3. Binder Samples. Sixteen binder samples have been prepared; one plain Portland cement CEM I (control), three binary binders with three replacement levels of $10 \%, 20 \%$, and 30\% VS (EN 197-1), three binary binders with three replacement levels of 5\%, 10\%, and 15\% LF (EN 197-1), and nine ternary binders containing both VS and LF as illustrated in Table $2.5 \%$ of gypsum were added to all the binder samples. All replacements were made by mass of cement. The clinker has been obtained from Adra Cement Plant, Damascus, Syria. All binder constituents have been ground by a laboratory grinding ball mill of $25 \mathrm{~kg}$ raw mix capacity. Limestone and volcanic scoria have separately been ground to $4100 \pm$ $100 \mathrm{~cm}^{2} / \mathrm{g}$ Blaine fineness, while the clinker and gypsum have been interground into $3600 \pm 50 \mathrm{~cm}^{2} / \mathrm{g}$. The Blaine fineness was measured using air permeability method in accordance with the European standard (EN 196-6). The particle size 


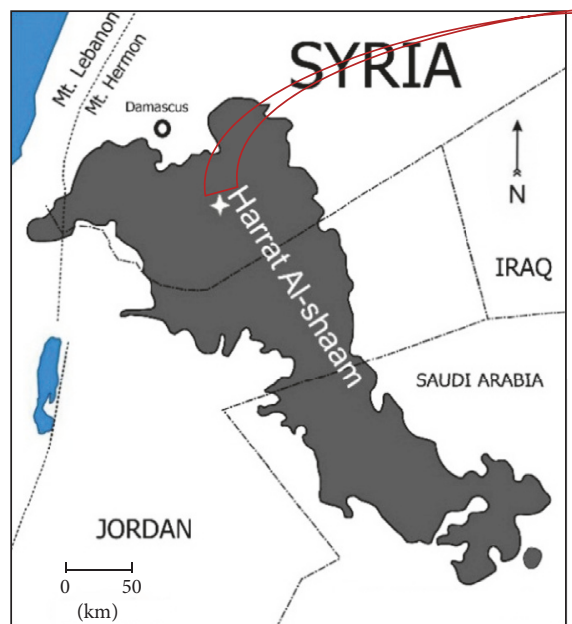

\& The studied site (Tal Shihan)

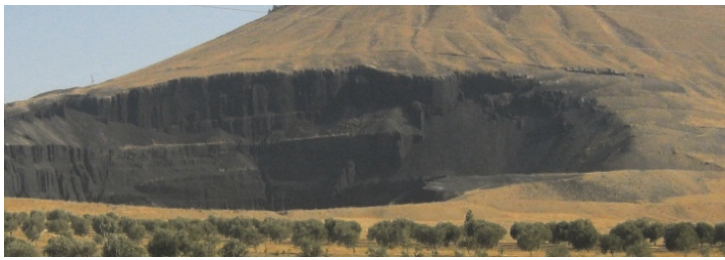

(b)

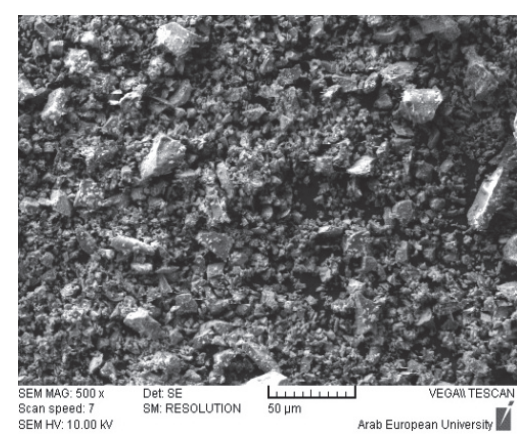

(c)

Figure 1: Map of Harrat Al-Shaam with a satellite view of the quarry. Photos of the studied quarry and the studied ground volcanic scoria. (a) Map of Harrat Al-Shaam with a satellite view of the studied area. (b) The studied volcanic scoria quarry. (c) SEM of the studied ground volcanic scoria.

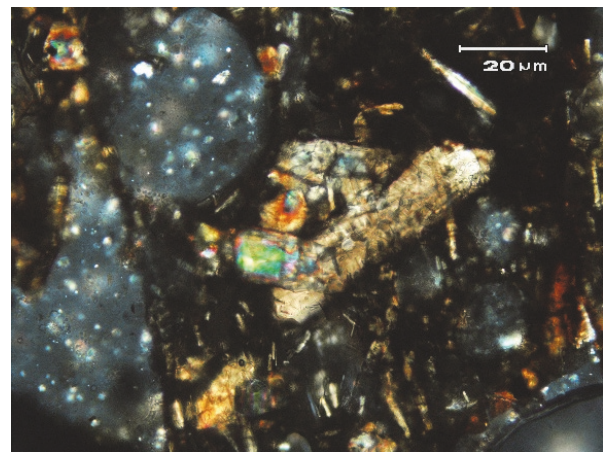

(a)

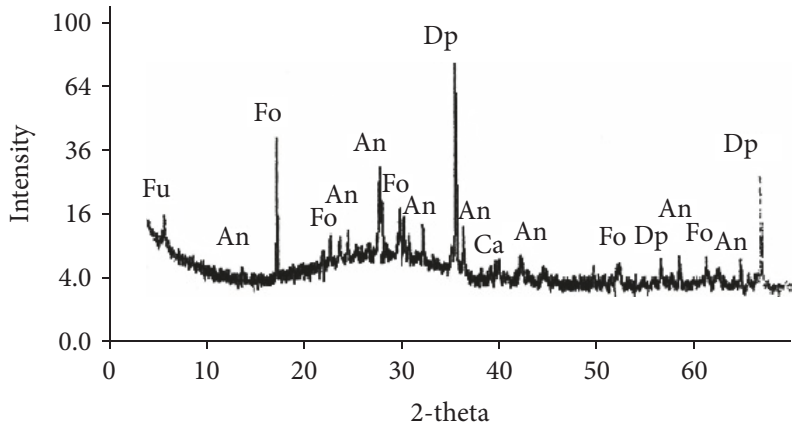

(b)

FIGURE 2: Petrographical examination and XRD analysis of the studied VS. (a) Microphenocrysts of olivine, pyroxene, and elongated plagioclase in volcanic glass matrix with vesicles, some of which are filled with white minerals. (b) XRD pattern of the studied VS. (Fo: Forsterite; An: Anorthite; Ca: Calcite; Dp: Diopside; Fu: Faujasite). 


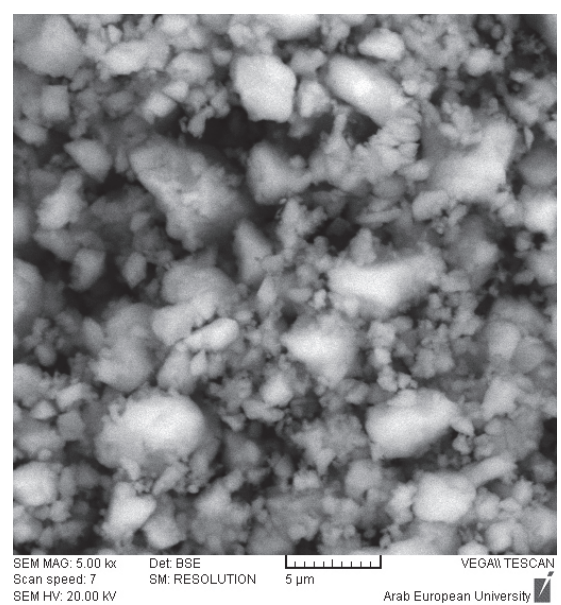

(a)

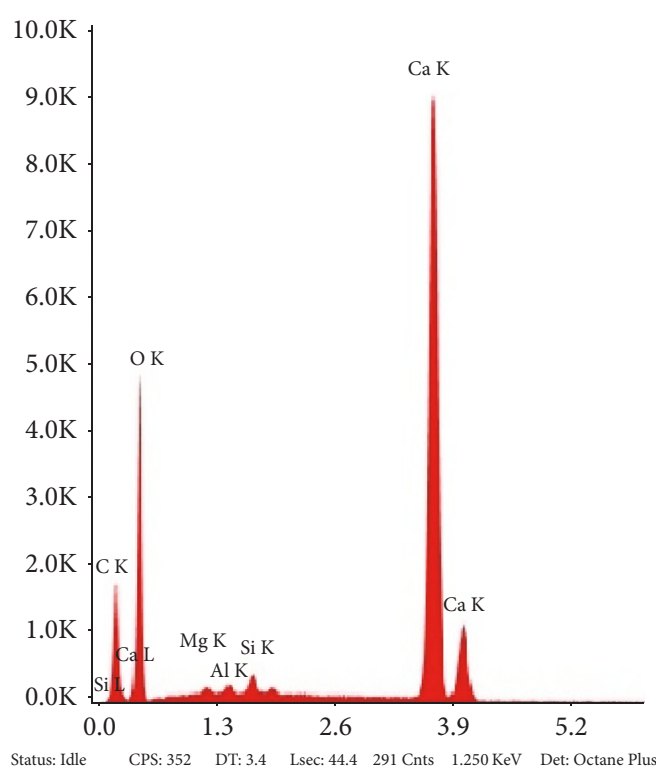

(b)

FIGURE 3: SEM and EDX of the studied ground limestone; (a) and (b), respectively.

distributions of the constituents have been obtained using Malvern Mastersizer 2000, a laser particle size analyzer, as shown in Figure 4. The median particle sizes of LF, VS, and OPC were about 9,13 , and $15 \mu \mathrm{m}$, respectively. All binders were designated according to the replacement levels. For instance, VS30LF5 refers to the binder containing 30\% and $5 \%$ of VS and LF, respectively.

2.4. Mortars. Mortar specimens of all binders used in the experiments have been prepared using these binders and sand meeting the requirements of ASTM C778. In all mixtures, binder: sand and water : binder (w/b) ratios were kept constant as $1: 2.75$ and 0.5 by weight, respectively. After being kept in (RH $\sim 95 \%)$ for 24 hours, the mortar specimens were demolded and kept in water at $22+2^{\circ} \mathrm{C}$ until the time of testing. No admixtures were used, as all mortar mixtures were mixable at this water-to-binder ratio.

2.5. Concrete. Sixteen concrete mixes have been prepared using grading of aggregate mixtures kept constant for all concrete mixes. Aggregates used in the study were crushed dolomite with natural sand added. Their quantities in $1 \mathrm{~m}^{3}$ concrete mix based on the oven-dry condition were as follows: $585.5 \mathrm{~kg}$ of coarse aggregate, $585.5 \mathrm{~kg}$ of mediumsize aggregate, $467.5 \mathrm{~kg}$ of crushed stone sand, and $312.5 \mathrm{~kg}$ of natural sand. All concrete mixes were designed to have a water-binder ratio of 0.5 and a slump of $150 \pm 20 \mathrm{~mm}$. Superplasticizer of "type F" (ASTM C494) was added. Concrete cubes $(150 \mathrm{~mm})$ were cast for the determination of compressive strength and water permeability.

2.6. Physical and Mechanical Properties of Pastes/Mortars. Water requirements, setting times, and soundness of all

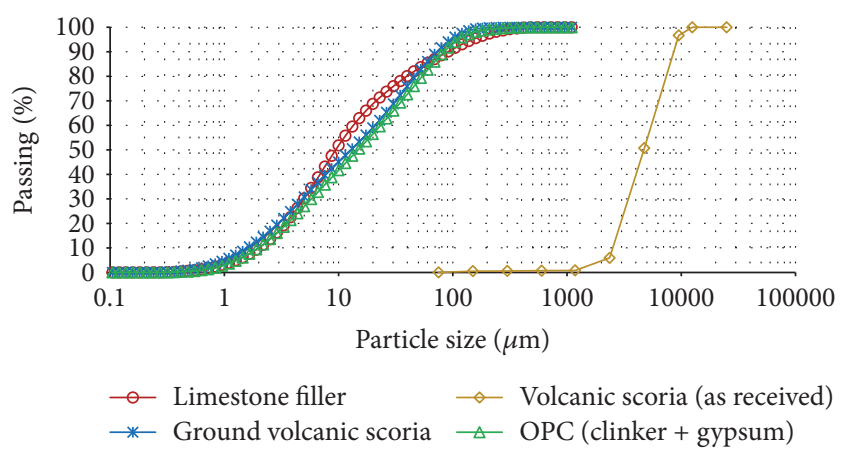

FIGURE 4: Particle size distribution of the materials used in the experimental part.

binder paste specimens have been determined in accordance with EN 196-3. Six-halved specimens obtained from the three mortar specimens used in the flexural strength tests have been tested for the determination of compressive strength of mortars under the same laboratory conditions as those applied in the flexural strength test. The compressive and flexural strength development was determined on $40 \times 40$ $\times 160 \mathrm{~mm}$ prismatic specimens, in accordance with EN 1961 , at ages of 2, 7, 28, and 90 days, respectively. The values reported in the results represent the average of six readings for compressive strength test and the average of three readings for all other tests.

2.7. Acid Attack Test. The relative acid resistance has been determined in accordance with ASTM C267 (2001). The aggressive acid environmental condition was simulated using $5 \%$ sulfuric acid $\left(\mathrm{H}_{2} \mathrm{SO}_{4}\right)$ of $\mathrm{pH} \sim 0.5$. The 28 days' cured 
TABLE 1: Chemical composition of the materials used in the study.

\begin{tabular}{|c|c|c|c|}
\hline \multirow{2}{*}{ Chemical composition (\%) } & \multicolumn{3}{|c|}{ Cementitious materials } \\
\hline & OPC (clinker + gypsum) & Volcanic scoria & Limestone filler \\
\hline $\mathrm{SiO}_{2}$ & 19.57 & 44.91 & 1.57 \\
\hline $\mathrm{Al}_{2} \mathrm{O}_{3}$ & 4.86 & 16.98 & 0.69 \\
\hline $\mathrm{Fe}_{2} \mathrm{O}_{3}$ & 3.50 & 8.64 & 0.33 \\
\hline $\mathrm{CaO}$ & 62.21 & 9.39 & 54.37 \\
\hline $\mathrm{MgO}$ & 2.78 & 8.87 & 0.43 \\
\hline $\mathrm{SO}_{3}$ & 2.12 & 0.01 & 0.01 \\
\hline Loss on ignition (LOI) & 1.36 & 0.36 & 42.22 \\
\hline $\mathrm{Na}_{2} \mathrm{O}$ & 0.22 & 2.76 & 0.02 \\
\hline $\mathrm{K}_{2} \mathrm{O}$ & 0.34 & 1.75 & 0.01 \\
\hline $\mathrm{TiO}_{2}$ & 0.6 & 0.9 & 0.07 \\
\hline $\mathrm{Cl}^{-}$ & 0.03 & - & 0.01 \\
\hline Insoluble residue & 1.67 & 5.01 & - \\
\hline Total & 99.26 & 99.58 & 99.73 \\
\hline \multirow{2}{*}{ Pozzolan activity index (ASTM C618) } & & 78 (at 7 days) & \\
\hline & & 89 (at 28 days) & \\
\hline \multicolumn{4}{|c|}{ Main compounds of ordinary Portland cement calculated according to Bogue's formulas } \\
\hline $\mathrm{C}_{3} \mathrm{~S}$ & 60.82 & & \\
\hline $\mathrm{C}_{2} \mathrm{~S}$ & 10.22 & & \\
\hline $\mathrm{C}_{3} \mathrm{~A}$ & 6.96 & & \\
\hline $\mathrm{C}_{4} \mathrm{AF}$ & 10.65 & & \\
\hline
\end{tabular}

TABLE 2: Mixtures used in the experimental investigation.

\begin{tabular}{lccc}
\hline Mix type & Clinker + gypsum & $\begin{array}{c}\text { Sample mixture (\%) } \\
\text { Limestone filler (LF) }\end{array}$ & Volcanic scoria (VS) \\
\hline VS0LF0 & 100 & 0 & 0 \\
VS0LF5 & 95 & 5 & 0 \\
VS0LF10 & 90 & 10 & 0 \\
VS0LF15 & 85 & 15 & 10 \\
VS10LF0 & 90 & 0 & 10 \\
VS10LF5 & 85 & 5 & 10 \\
VS10LF10 & 80 & 10 & 10 \\
VS10LF15 & 75 & 15 & 20 \\
VS20LF0 & 80 & 0 & 20 \\
VS20LF5 & 75 & 5 & 20 \\
VS20LF10 & 70 & 10 & 20 \\
VS20LF15 & 65 & 15 & 30 \\
VS30LF0 & 70 & 0 & 30 \\
VS30LF5 & 65 & 5 & 30 \\
VS30LF10 & 60 & 10 & 30 \\
VS30LF15 & 55 & 15 & \\
\hline
\end{tabular}




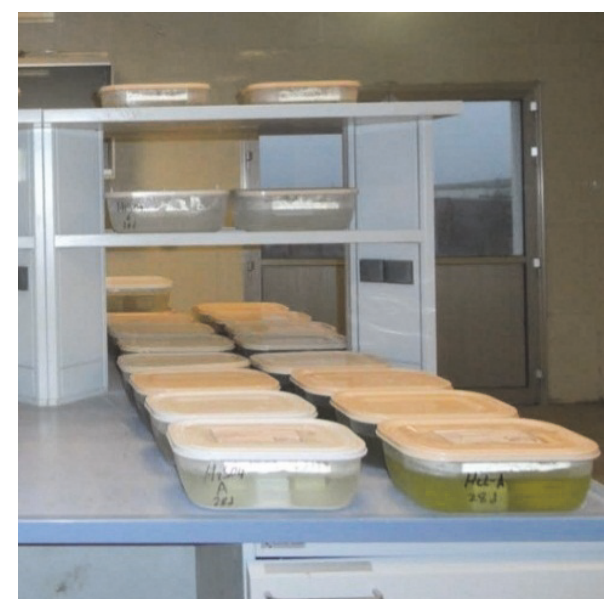

Figure 5: Photo of the Plexiglas containers with immersed mortar specimens.

mortar cubes were immersed in the aggressive acid environment for 90 days. The Plexiglas containers with immersed mortar specimens were kept covered throughout the testing period to minimize the evaporation, as shown in Figure 5. At $2,7,14,28,56$, and 90 days of exposure, the mortar specimens were cleaned with distilled water; then the acid resistance was evaluated through measurement of the weight loss of the specimens determined as follows:

$$
\text { Weight loss }(\%)=\left[\frac{\left(W_{1}-W_{t}\right)}{W_{1}}\right] \times 100 \text {, }
$$

where $W_{1}$ is the weight (grams) of the specimens before immersion and $W_{t}$ is the weight (grams) of cleaned specimens after $t$ day immersion. The average weight losses for each mortar specimens have been reported.

2.8. Concrete Permeability. Concrete permeability measured in terms of depth of water penetration has been carried out as per the standard EN 12390-8. The results shown in this paper are the average penetration depth.

\section{Results and Discussion}

3.1. Properties of Volcanic Scoria and Limestone Filler. As seen from Table 1, volcanic scoria is considered as suitable material for use as cement replacement. It satisfied the standards requirements for such a material by having a combined $\mathrm{SiO}_{2}$, $\mathrm{Al}_{2} \mathrm{O}_{3}$, and $\mathrm{Fe}_{2} \mathrm{O}_{3}$ of more than $70 \%$, a $\mathrm{SO}_{3}$ content of less than $4 \%$, and a loss on ignition of less than 10\% (ASTM C618:2001). $\mathrm{SiO}_{2 \text { reactive }}$ content is more than $25 \%$, as well (EN 197-1). In addition, it has a strength activity index with PC higher than the values specified in ASTM C618 (2001).

The chemical composition of limestone filler has been found to be $55 \% \mathrm{CaO}\left(\mathrm{CaCO}_{3}\right.$ ratio is about $\left.97 \%\right)$ with a loss on ignition value of $43 \%$. Furthermore, some impurities such as $\mathrm{MgO}, \mathrm{Fe}_{2} \mathrm{O}_{3}, \mathrm{SO}_{3}, \mathrm{SiO}_{2}$, and $\mathrm{Al}_{2} \mathrm{O}_{3}$ have been determined where their total amount is about $3 \%$. The total organic content and clay content of the studied limestone have been determined as $0.36 \%$ and $0.56 \%$, respectively. According to EN 197-1 standard, it is possible to classify these cements as CEM II/A-L (group L: TOC is between $0.5 \%$ and $0.2 \%$ ). In addition, according to this standard, the $\mathrm{CaCO}_{3}$ ratio of limestone employed in the production of blended cement should be at least $75 \%$, and the clay content of limestone should not exceed $1.2 \%$. Based on the analysis results, the studied limestone can be used as ingredient in cement production.

\subsection{Physical Properties of Binder Pastes}

3.2.1. Water Requirements. The results of water requirements are given in Figure 6(a). Binary binders containing VS have, to some extent, a greater water demand. However, as it can be seen from Figure 6(a), there is no significant change in the water content even for the binder containing 30\% VS which increased only by less than 3\% compared to CEM I. This could be explained by the lubricant effect of natural pozzolan on paste when finely divided $[1,18]$ and the effect of VS shape which was characterized by shape-edged grain [19]. The limestone filler, despite its higher fineness, generally demands less water than the corresponding pure cement. This is due to the wider particle size distribution of limestone filler [20]. The particle size distribution of the clinker, which is harder to grind, is narrower, with a slope equal to 0.88 on a RosinRammler diagram, as shown in Figure 6(b). That of the more easily ground limestone, on the other hand, is wider, with a slope of 0.69 . These results are in good agreement with those reported by Sprung and Siebel [21]. Further, no significant change in water demand was observed in the ternary binders as compared with the control.

3.2.2. Setting Times. Figure 7 illustrates the setting times of the control paste and pastes containing VS, LF, or both. The results showed that the setting times slightly increased with VS replacement level. This could be due to the increase of water demand $[7,22]$ and the pozzolanic reaction between the glassy phase in VS and $\mathrm{CH}$ liberated during hydration of $\mathrm{C}_{3} \mathrm{~S}$ and $\mathrm{C}_{2} \mathrm{~S}$ of clinker, which is, usually, slower than the hydration of cement [7].

The initial setting times, by contrast, decreased with the increase of LF replacement ratio indicating the acceleration effect of $\mathrm{CaCO}_{3}$ on the hydration of $\mathrm{C}_{3} \mathrm{~A}$ to form sulfoaluminate and of $\mathrm{C}_{3} \mathrm{~S}$ to form $\mathrm{CSH}$ and $\mathrm{CH}$ in cement. The acceleration of setting times reached a maximum of $50 \mathrm{~min}$ when 5\% LF was used. This is in well agreement with the results reported by Kenai et al. [23]. The influence of adding LF can easily be seen in Figure 7. While VS30LF0-based paste has initial setting time of $194 \mathrm{~min}$, the VS30LF5- and VS30LF10-based pastes showed a significant reduction in initial setting times of about 17 and $23 \mathrm{~min}$, respectively.

It is worthwhile to note that all the investigated binders are seen to comply with the standard requirements (initial setting time $\geq 45 \mathrm{~min}$ and final setting time $\leq 420 \mathrm{~min}$ ) according to ASTM C595.

A plot of the initial setting time against the final setting time for the whole tested samples as shown in Figure 8 indicates that there is a strong correlation between the parameters as the coefficient of determination $\left(R^{2}\right)$ was calculated to be 


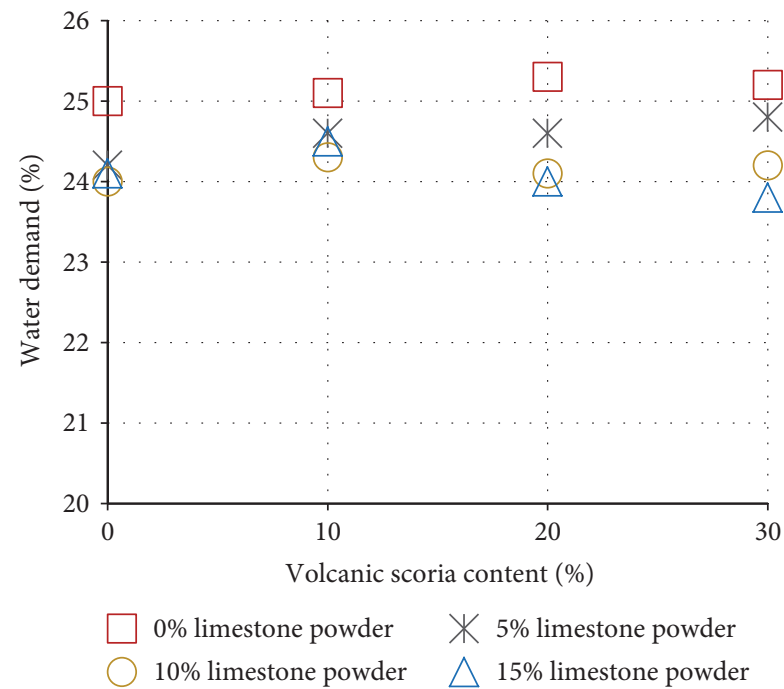

(a)

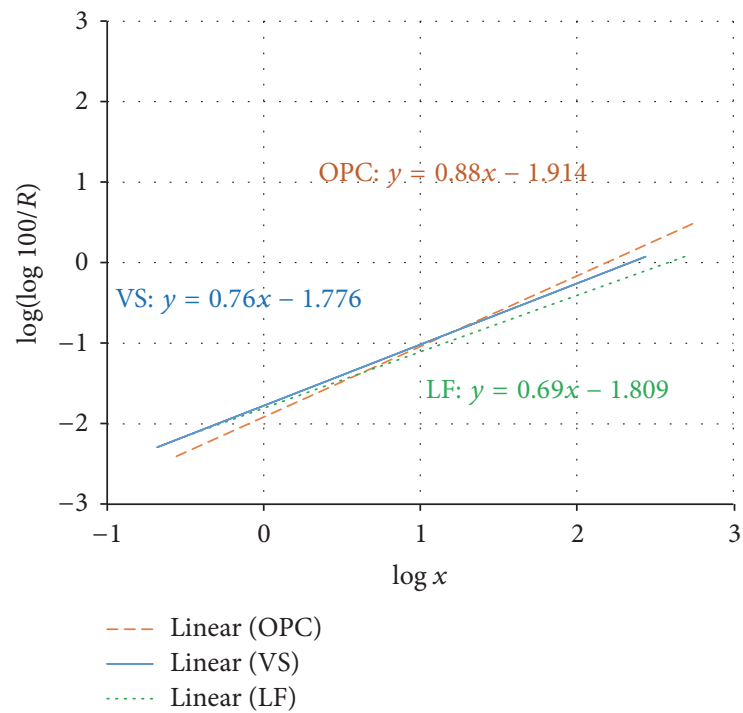

(b)

FIGURE 6: Water demand of the investigated binder pastes and Rosin-Rammler diagram. (a) Water demand of the investigated pastes. (b) Rosin-Rammler diagram ( $x$ : particle size; $R$ : cumulative retained).

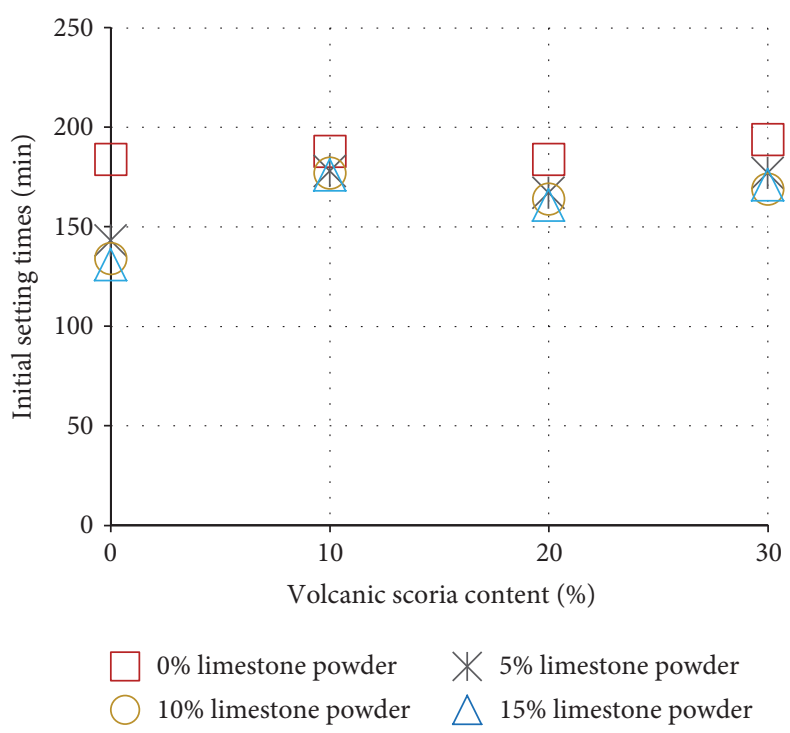

(a)

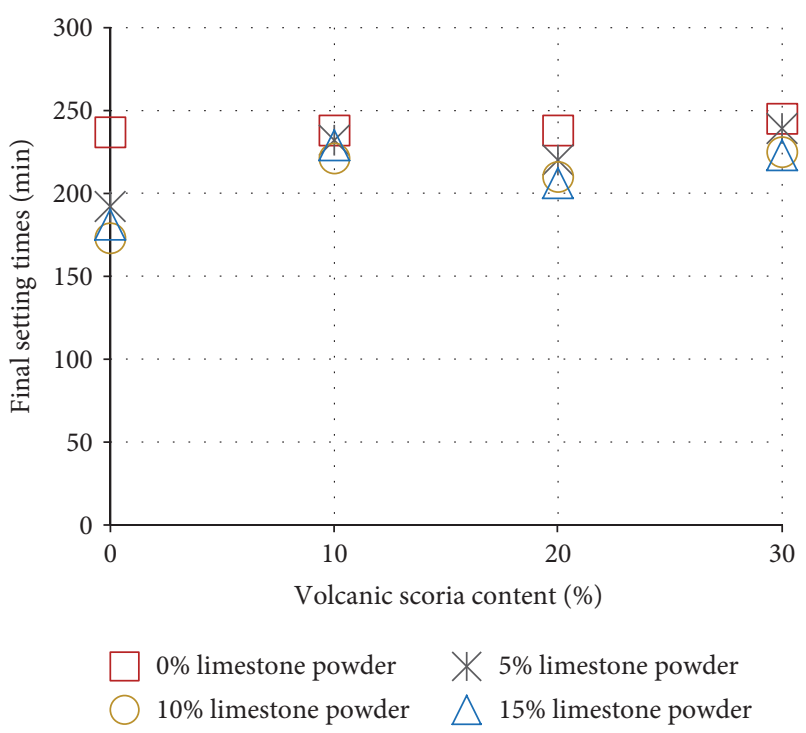

(b)

FIGURE 7: Initial and final setting times of the investigated binder pastes. (a) Initial setting times of the investigated pastes; (b) final setting times of the investigated pastes.

0.95 . A strong relationship exists between two variables when $R^{2} \geq 0.85$ [24]. Thus, an estimate of the final setting time can be predicted from (2) when the initial setting time has been obtained.

$$
\mathrm{FST}=1.14 \mathrm{IST}+27.43 \quad\left(R^{2}=0.95\right)
$$

where FST is final setting time (min) and IST is initial setting time (min).
3.2.3. Soundness. According to the experimental results of volume stability determined by the Le Chatelier accelerated test, the soundness of all studied binders was satisfactory. It can be said that most of them recorded values of less than $0.5 \mathrm{~mm}$ which is much less than the maximum value of $10 \mathrm{~mm}$ allowed by En 197-1. Interpretation of these results is currently beyond the author's understanding and needs further investigation. Nevertheless, these results could be attributed, to some extent, to the reduction in $\mathrm{CaO}_{\text {free }}$ and $\mathrm{MgO}_{\text {reactive }}$ compounds which create the swelling effect. 
TABLE 3: Compressive strength development of mortars.

\begin{tabular}{|c|c|c|c|c|}
\hline \multirow{2}{*}{ Mix type } & \multicolumn{4}{|c|}{ Compressive $\left(f_{c m}\right)$ strength of mortars $(\mathrm{MPa})$, normalized } \\
\hline & 2 days' curing & 7 days' curing & 28 days' curing & 90 days' curing \\
\hline VSOLF0 & $20.6-100 \%$ & $39.6-100 \%$ & $48.7-100 \%$ & $54.9-100 \%$ \\
\hline VSOLF5 & $20.5-100 \%$ & $38.9-98 \%$ & $48.9-100 \%$ & $54.5-99 \%$ \\
\hline VS0LF10 & $19.9-97 \%$ & $37.1-94 \%$ & $46.6-96 \%$ & $52.8-96 \%$ \\
\hline VS0LF15 & $14.8-72 \%$ & $32.6-82 \%$ & $44.1-91 \%$ & $49.1-89 \%$ \\
\hline VS10LF0 & $16.2-79 \%$ & $32.1-81 \%$ & $45.9-94 \%$ & $54.2-99 \%$ \\
\hline VS10LF5 & $15.7-76 \%$ & $31.7-80 \%$ & $45.5-93 \%$ & $53.4-97 \%$ \\
\hline VS10LF10 & $14.6-71 \%$ & $29.1-73 \%$ & $42.1-86 \%$ & $50.5-92 \%$ \\
\hline VS10LF15 & $10.4-51 \%$ & $27.3-69 \%$ & $36.8-76 \%$ & $45.4-83 \%$ \\
\hline VS20LF0 & $11.9-58 \%$ & $28.9-73 \%$ & $39.1-81 \%$ & $49.1-89 \%$ \\
\hline VS20LF5 & $11.9-58 \%$ & $28.0-71 \%$ & $37.9-78 \%$ & $48.2-88 \%$ \\
\hline VS20LF10 & $11.6-56 \%$ & $27.6-70 \%$ & $37.5-77 \%$ & $48.1-88 \%$ \\
\hline VS20LF15 & $8.8-43 \%$ & $23.1-58 \%$ & $33.5-69 \%$ & $43.3-79 \%$ \\
\hline VS30LF0 & $8.3-40 \%$ & $24.1-61 \%$ & $34.4-71 \%$ & $47.8-87 \%$ \\
\hline VS30LF5 & $8.4-41 \%$ & $23.3-59 \%$ & $33.5-69 \%$ & $44.2-81 \%$ \\
\hline VS30LF10 & $7.8-38 \%$ & $21.8-55 \%$ & $31.4-64 \%$ & $42.3-77 \%$ \\
\hline VS30LF15 & $6.9-34 \%$ & $18.6-47 \%$ & $26.8-55 \%$ & $38.8-71 \%$ \\
\hline
\end{tabular}

TABLE 4: Compressive strength development of concrete.

\begin{tabular}{lcccc}
\hline \multirow{2}{*}{ Mix type } & \multicolumn{3}{c}{ Compressive $\left(f_{c}\right)$ strength of concrete (Mpa), normalized } \\
& 2 days' curing & 7 days' curing & 28 days' curing & $47.9-100 \%$ \\
\hline VS0LF0 & $18.1-100 \%$ & $34.3-100 \%$ & $42.1-100 \%$ & $41.3-98 \%$ \\
VS0LF5 & $18.2-101 \%$ & $34.2-100 \%$ & $40.0-95 \%$ & $45.5-95 \%$ \\
VS0LF10 & $17.8-98 \%$ & $33.3-97 \%$ & $35.9-85 \%$ & $49.1-86 \%$ \\
VS0LF15 & $13.3-73 \%$ & $27.2-79 \%$ & $40.1-95 \%$ & $46.9-98 \%$ \\
VS10LF0 & $14.6-80 \%$ & $28.1-82 \%$ & $39.4-94 \%$ & $46.0-96 \%$ \\
VS10LF5 & $13.9-77 \%$ & $28.0-82 \%$ & $36.8-87 \%$ & $43.2-90 \%$ \\
VS10LF10 & $13.2-73 \%$ & $26.0-76 \%$ & $31.3-74 \%$ & $37.8-79 \%$ \\
VS10LF15 & $9.7-54 \%$ & $22.7-66 \%$ & $34.2-81 \%$ & $43.7-91 \%$ \\
VS20LF0 & $10.5-58 \%$ & $23.3-68 \%$ & $34.5-82 \%$ & $43.6-91 \%$ \\
VS20LF5 & $10.8-60 \%$ & $24.7-72 \%$ & $33.7-80 \%$ & $43.1-90 \%$ \\
VS20LF10 & $10.7-59 \%$ & $23.4-68 \%$ & $30.4-72 \%$ & $38.6-81 \%$ \\
VS20LF15 & $8.1-45 \%$ & $19.0-55 \%$ & $32.3-77 \%$ & $47.8-89 \%$ \\
VS30LF0 & $7.7-43 \%$ & $20.6-60 \%$ & $30.3-72 \%$ & $40.1-84 \%$ \\
VS30LF5 & $7.7-43 \%$ & $19.3-56 \%$ & $29.1-69 \%$ & $38.6-81 \%$ \\
VS30LF10 & $7.4-41 \%$ & $17.6-51 \%$ & $24.9-59 \%$ & $35.6-74 \%$ \\
VS30LF15 & $6.7-37 \%$ & $14.9-43 \%$ & & \\
\hline
\end{tabular}

\subsection{Mechanical Strengths of Mortars/Concrete}

3.3.1. Compressive Strength of Mortars/Concrete. The results of compressive strength development for all mortar/concrete mixes containing varying amounts of VS, LF, or both are given in Tables 3 and 4, respectively. As expected, all mortars/concrete show an increase in strength with curing time. Mortar/concrete specimens containing CEM I have almost higher compressive strengths at any curing time compared to binary or ternary binders. Also, it is seen that the compressive strength of mortars/concrete containing VS decreases with the replacement level for all curing times. For instance, the compressive strength of plain mortars and mortars containing 30\% VS after 7 days' curing decreased from 39.6 to $24.1 \mathrm{MPa}$, respectively. This could be explained by (i) the reduction of cement content in the mix with the increase of VS content, that is, the dilution effect [25], and (ii) the slowness of the pozzolanic reaction between the glassy phase in VS and the $\mathrm{CH}$ released during cement hydration. However, due to the continuation of this reaction and the formation of a secondary CSH, a greater degree of hydration is achieved resulting in strengths after 90 days' curing which are comparable to those of plain mortars [1]. For instance, the compressive strength of VS30LF0-based mortar was found to be $39 \%$ lower than plain mortar at 7 days' curing, but this reduction was only $13 \%$ after 90 days' curing. The significant 


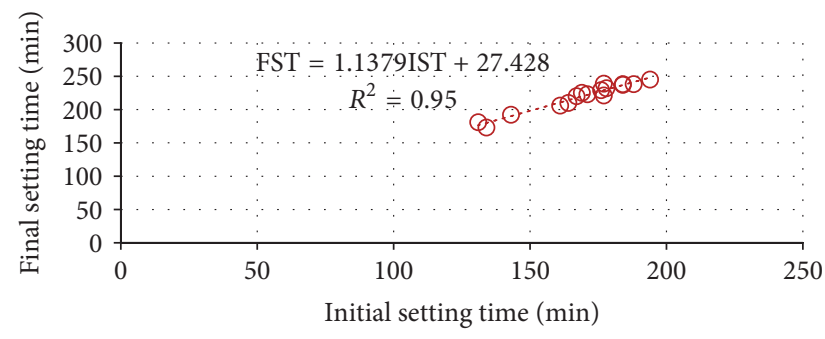

FIGURE 8: Correlation between initial and final setting times of the investigated binders.

gain in strength in mortars containing VS occurred when moving from 28 to 90 days' curing times while in plain mortar specimens this was noted during the first 28 days. This could be explained by the slow pozzolanic reaction and its progress with age in VS-based binder mortars.

The strengths of mortars containing LF were not affected by replacement of cement with LF content up to $10 \%$. The early strength was improved by substituting $5 \% \mathrm{LF}$ while after 90 days of curing the strength of mortars prepared with 5\% LF was slightly lower than those prepared without LF. The increase in the early strength of the mortar due to the addition of $5 \% \mathrm{LF}$ can be attributed to its active participation in cement hydration and filler effect of the fine particles of LF [13]. The additional surface area supplied by the limestone particles may provide sites for the nucleation and growth of hydration products that leads to further increase in strength $[13,26]$. Further, despite the fact that the limestone filler has no pozzolanic property (i.e., it does not produce CSH) [27, 28], limestone particles contribute to the strength development by forming new hydration products like carboaluminate phases and by reducing the pore ratio [26]. According to Vuk et al. [29], Schmidt [30], and Voglis et al. [31], early strength increased with the use of $5 \%$ limestone; however, later strengths either remained the same or decreased relatively to the control. When LF is included in large quantities (15\%) it acts as a diluent, so that strengths are lower than for comparable Portland cements. This is consistent with the findings reported by Sprung and Siebel [21] and Celik et al. [32].

The positive effect of adding LF on the early strength of 2 days' cured mortar can easily be seen in Table 3 . For instance, the compressive strength increased from $8.3 \mathrm{MPa}$ to $11.6 \mathrm{MPa}$ when replacing $10 \%$ VS by $10 \%$ LF in the VS30LF0 mix and from 11.9 MPa to $14.6 \mathrm{MPa}$ when replacing $10 \%$ VS by $10 \% \mathrm{LF}$ in the VS20LF0 mix. On the other hand, the positive effect of VS on the later-age strength can also be observed from Table 3. For instance, replacing $10 \%$ LF by $10 \%$ VS in the VS0LF15 resulted in an increase in compressive strength by about $8 \%$. This substitution confirmed the contribution of VS in the strength development through the pozzolanic reaction. Such positive synergy with regard to mechanical strength of concrete has also been reported by other researchers who studied ternary blended mixtures of OPC, limestone powder and fly ash, metakaolin, slag, or natural pozzolan $[9,28,33-$ 38].

Further, an interesting result has also to be reported. The binder containing $20 \%$ VS has compressive strengths similar

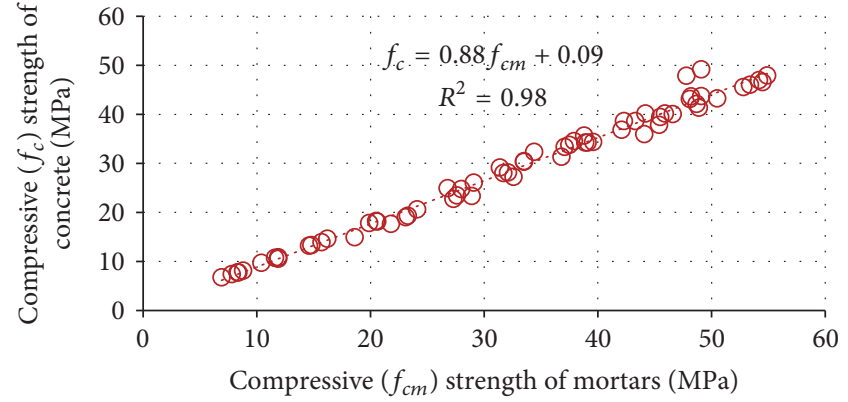

FIGURE 9: Correlation between the compressive strength of concrete and that of mortar of the same $\mathrm{w} / \mathrm{b}$ ratio.

to that containing $20 \%$ VS and 5 or $10 \%$ LF. This means that replacing 5 or $10 \%$ of OPC with 5 or $10 \%$ LF does not impair the compressive strength even at later ages. The result shows that the cement producers could burn 5 or $10 \%$ less clinker and instead add LF. This is both economically and ecologically beneficial, as less energy is needed and less $\mathrm{CO}_{2}$ will be emitted.

Strength of concrete is commonly considered its most valuable property, although, in many practical cases, other characteristics, such as durability and permeability, may in fact be more important [39]. Compressive strengths of concrete presented in Table 4 have a trend similar to that noted in mortars. The correlation between the compressive strength of VS-based mortars and the compressive strength of VS-based concrete is given in Figure 9. The compressive strength of VS-based concrete seems to have a close relationship with that of volcanic-scoria-based mortars. A linear regression analysis was conducted to determine the best-fit relationship between all the measured compressive strengths of mortars and concrete for all curing times. The following linear equation was derived based on the analysis with a regression coefficient of 0.98 :

$$
f_{c}=0.88 f_{c m}+0.09 \text {, }
$$

where $f_{c}, f_{c m}$ are compressive strength of concrete and mortars in $\mathrm{MPa}$, respectively. So, the compressive strength of concrete at a given curing time can be predicted from a knowledge of the compressive strength of mortar prepared with the same $\mathrm{w} / \mathrm{b}$ ratio. This linear equation is in good agreement with that reported by Neville [39] for plain mortar and concrete. Such similar relationships may need to be developed for other types of aggregates, different $\mathrm{w} / \mathrm{c}$ ratios, and other curing conditions.

3.3.2. Flexural Tensile Strength of Mortars. Results of flexural tensile strength of the prisms prepared from the produced binder mortars and cured in water until the test dates are arranged in Table 5. The values given in Table 5 show the average of flexural tensile strength for 3 samples. A similar trend to that observed for compressive strength seems to be followed by the flexural strength results. However, the results show that flexural strength is less sensitive than the compressive strength to the addition of VS, LF, or both. 
TABLE 5: Flexural strengths of the investigated mortars after various curing times.

\begin{tabular}{|c|c|c|c|c|}
\hline \multirow{2}{*}{ Mix type } & \multicolumn{4}{|c|}{ Flexural strength $(\mathrm{MPa})$} \\
\hline & 2 days' curing & 7 days' curing & 28 days' curing & 90 days' curing \\
\hline VSOLF0 & 4.8 & 6.8 & 7.6 & 8.1 \\
\hline VS0LF5 & 3.8 & 6.4 & 8 & 8 \\
\hline VS0LF10 & 3.5 & 6.9 & 7.7 & 7.6 \\
\hline VS0LF15 & 2.7 & 6.1 & 7.1 & 7.8 \\
\hline VS10LF0 & 4.3 & 5.9 & 7.4 & 7.8 \\
\hline VS10LF5 & 3.6 & 5.5 & 7.2 & 7.6 \\
\hline VS10LF10 & 3.8 & 6.0 & 7.1 & 7.6 \\
\hline VS10LF15 & 2.3 & 5.4 & 6.5 & 7.2 \\
\hline VS20LF0 & 2.8 & 5.4 & 6.8 & 7.3 \\
\hline VS20LF5 & 3.5 & 5.1 & 7.1 & 7.5 \\
\hline VS20LF10 & 2.7 & 5.4 & 6.7 & 7.4 \\
\hline VS20LF15 & 2.2 & 4.7 & 6.5 & 7.5 \\
\hline VS30LF0 & 2.2 & 4.9 & 6.4 & 7.4 \\
\hline VS30LF5 & 2.1 & 4.1 & 6.3 & 7.4 \\
\hline VS30LF10 & 2.2 & 4.4 & 6.6 & 7.3 \\
\hline VS30LF15 & 1.8 & 3.8 & 5.6 & 7.2 \\
\hline
\end{tabular}

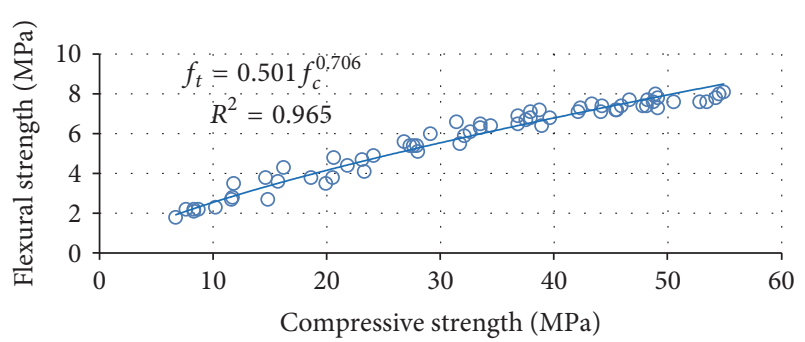

FIGURE 10: Correlation between flexural and compressive strength of the investigated mortars.

3.3.3. Correlation between Compressive and Flexural Strength of Mortars. The correlation between the flexural strength and the compressive strength results were calculated for the entire population of mortar test results as shown in Figure 10, and hence the relation obtained is

$$
f_{t}=0.5\left(f_{c}\right)^{0.7}
$$

with a correlation factor $\left(R^{2}\right)$ of 0.97 . So, knowing the compressive strength $f_{c}$ of mortar, the flexural strength $f_{t}$ can be predicted using (4). This relation is similar to those reported in the literature [39].

3.3.4. Correlation between Mechanical Strengths and Supplementary Materials Content. According to the test results, the mechanical strength of mortars containing VS, LF, or both seems to have a close relationship with the content of these additions. For each testing age, linear regression analysis was conducted to determine the best-fit relationship between measured mechanical strengths (compressive and flexural strengths) for all mixtures prepared according to the experimental design and the varying parameters. The independent variables of VS percentage and LF percentage were employed in the following two estimation equations (5) derived by the authors:

$$
f_{c} ; f_{t}=a_{1}+a_{2} \times \mathrm{VS}+a_{3} \times \mathrm{LF}+a_{4} \times \mathrm{VS} \times \mathrm{LF},
$$

where $f_{c}, f_{t}$ are compressive and flexural strength of mortars in $(\mathrm{MPa})$, respectively; VS is the volcanic scoria content; LF is the limestone filler content; $a_{1}, a_{2}, a_{3}, a_{4}$ are constants. So, the compressive and flexural strengths of mortars at a given curing time can be predicted from knowledge of VS content and LF content.

Table 6 presents the constants $\left(a_{1}, a_{2}, a_{3}, a_{4}\right)$ with regression coefficients $\left(R^{2}\right)$ of the correlation between the experimental data and the proposed equation. However, it should be emphasized that additional factors including the type of natural pozzolan or limestone, composition and strength of clinker, w/b ratio, and fineness of the mix ingredients may also be important parameters.

From the values shown in Table 6, it should be noted that the highest $R^{2}$ values were found in the correlation between compressive strengths and the supplementary materials contents.

Generally, as can be seen from the correlation values, the predicted values were in good agreement with the measured values obtained in the study.

3.4. Acid Attack. Most investigations have considered weight loss as acceptable indicator for evaluating the resistance of concrete to acid attack. Weight change was determined for all mortars stored in 5\% sulfuric acid solution. The results of weight losses of 28 days' cured mortar specimens according to exposure time are presented in Figure 11.

As expected, the acid resistance of the mortars improves with increasing the replacement level of VS. All mortars containing VS had lower weight loss than the control mortar at the ages of $2,7,14,28,56$, and 90 days. This improvement 
TABLE 6: Constants $a_{1}, a_{2}, a_{3}$, and $a_{4}$ and regression coefficient $\left(R^{2}\right)$ of the correlation between the experimental data and the proposed equations.

\begin{tabular}{|c|c|c|c|c|c|c|}
\hline Curing time (day) & Mechanical strength & $a_{1}$ & $a_{2}$ & $a_{3}$ & $a_{4}$ & $R^{2}$ \\
\hline \multirow{2}{*}{2} & $f_{c}$ & 21.5 & -44 & -40.1 & 94.8 & 0.927 \\
\hline & $f_{t}$ & 4.9 & -8.5 & -13.9 & 39.4 & 0.856 \\
\hline \multirow{2}{*}{7} & $f_{c}$ & 39.3 & -51.1 & -41.7 & 35 & 0.959 \\
\hline & $f_{t}$ & 6.7 & -6.6 & -2.2 & -10 & 0.914 \\
\hline \multirow{2}{*}{28} & $f_{c}$ & 50.3 & -51.1 & -39.9 & -18.6 & 0.958 \\
\hline & $f_{t}$ & 7.9 & -4.5 & -4.2 & 1.2 & 0.811 \\
\hline \multirow{2}{*}{90} & $f_{c}$ & 56.5 & -29.7 & -42 & -37 & 0.930 \\
\hline & $f_{t}$ & 8 & -2.4 & -2.9 & 8.2 & 0.671 \\
\hline
\end{tabular}

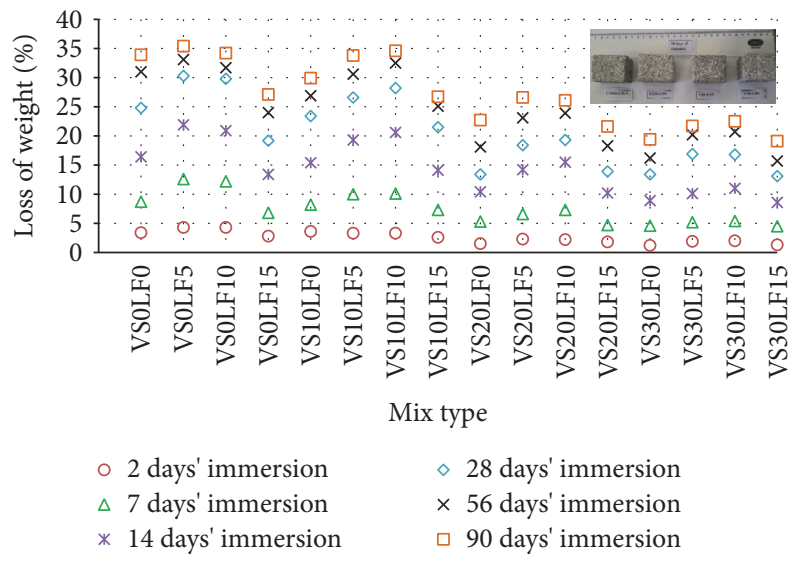

FIGURE 11: Weight losses over time of 28 days' cured mortars immersed in $5 \% \mathrm{H}_{2} \mathrm{SO}_{4}$.

of acid resistance is higher at early ages and decreases with increasing the immersion time. The weight loss of the mortars containing $30 \% \mathrm{VS}$ was much less than half of the weight loss of plain mortar at the first 2 and 7 days of exposure. The better performance of VS-based cements can be due to the pozzolanic reaction $[40,41]$. This reaction between VS and calcium hydroxide liberated during the hydration of cement led to a refinement of the pore structure resulting in a highly impermeable matrix $[1,40,41]$. This was confirmed by the results of concrete permeability test. The pozzolanic reaction also fixes $\mathrm{Ca}(\mathrm{OH})_{2}$, which is usually the most vulnerable product of hydration of cement in so far as acid attack is concerned [39]. In addition, as highly alkaline cements are good willing partners for acid attack [42], replacing a portion of cement with a less-alkaline pozzolanic material decreases the total amount of the present alkali. Further, pozzolans react with calcium hydroxide to form calcium silicate hydrate with a low $\mathrm{CaO} / \mathrm{SiO}_{2}$ ratio. The creation of calcium aluminate hydrates (CASH-ASH, CAH) in the VS-based mortar also contributes in increasing the chemical resistance of such a mortar. It is believed that CAH may be more chemically stable in highly acidic environments than $\mathrm{CSH}[43,44]$.

Mortars containing up to $10 \%$ limestone filler showed higher loss of weight values at all immersion times. This could be due to the presence of calcium carbonate, $\mathrm{CaCO}_{3}$, the main compound in the limestone, which easily suffers from acid attack. This result, which is in good agreement with the result of Bassuoni et al. (2007) [45], can also be attributed to the highly aggressive sulfuric acid solution (i.e., $5 \%$ concentration) and the relatively high fineness of LF (i.e., $4100 \mathrm{~cm}^{2} / \mathrm{g}$ ). As clearly seen in Figure 12(a), after 14 days of exposure to $5 \% \mathrm{H}_{2} \mathrm{SO}_{4}$, the deteriorated VSOLF5-based mortar showed a structure of relatively high porosity with some crystals of gypsum and $\mathrm{CSH}$ phases of low $\mathrm{Ca} / \mathrm{Si}$ ratio. This relatively low ratio, according to the authors, might be due to the partial decalcification of $\mathrm{CSH}$.

However, contrary to expectation, the weight loss of mortars containing $15 \%$ limestone filler was much less than the plain mortar when exposed to $5 \% \mathrm{H}_{2} \mathrm{SO}_{4}$. Moreover, the better performance with regard to the sulfuric acid resistance was noted when adding $15 \%$ LF to the VS-based mortars. This can be attributed to the following main factors: (i) LF was finer than OPC. It filled the micropores in mortar and the ability of mortar to resist acidic attack was improved by the reduced permeability and porosity, (ii) the presence of high calcium carbonate $\left(\mathrm{CaCO}_{3}\right)$ content increased the capacity of limestone mortars to consume more aggressive acid, (iii) the decreased proportion of cement reduced the portlandite $(\mathrm{CH})$ content, (iv) addition of calcium carbonate will bring the calcium and thus maintain the protection of CSH of decalcification [46], (v) as LF content of $15 \%$ is the highest, a lot of gypsum from reaction between $\mathrm{CaCO}_{3}$ and sulfuric acid will form [47]. This layer of gypsum can be capable of retarding the deterioration process by acting as a surface sealing layer [48]. Moreover, this layer has very low solubility in water [49]. This result was confirmed by SEM and EDX analysis, as shown in Figure 12(b), and (vi) carbonate ions from limestone compete against sulfate ions to react with C3A of cement [50]. As generally expected, none of the binders used can provide a long-term resistance when exposed to strong acids.

3.5. Water Permeability of Concrete. Permeability of concrete to water is closely related to the durability of concrete. Water penetration depth can be considered as an indication of permeable and impermeable concrete [39]. A depth of less than $50 \mathrm{~mm}$ classifies the concrete as impermeable and a depth of less than $30 \mathrm{~mm}$ as impermeable under aggressive conditions [39]. Figure 13 shows the water penetration depth test results for all binder types. Concrete containing VS-, LF-, or VSLF-based binders is supposed to have lower 

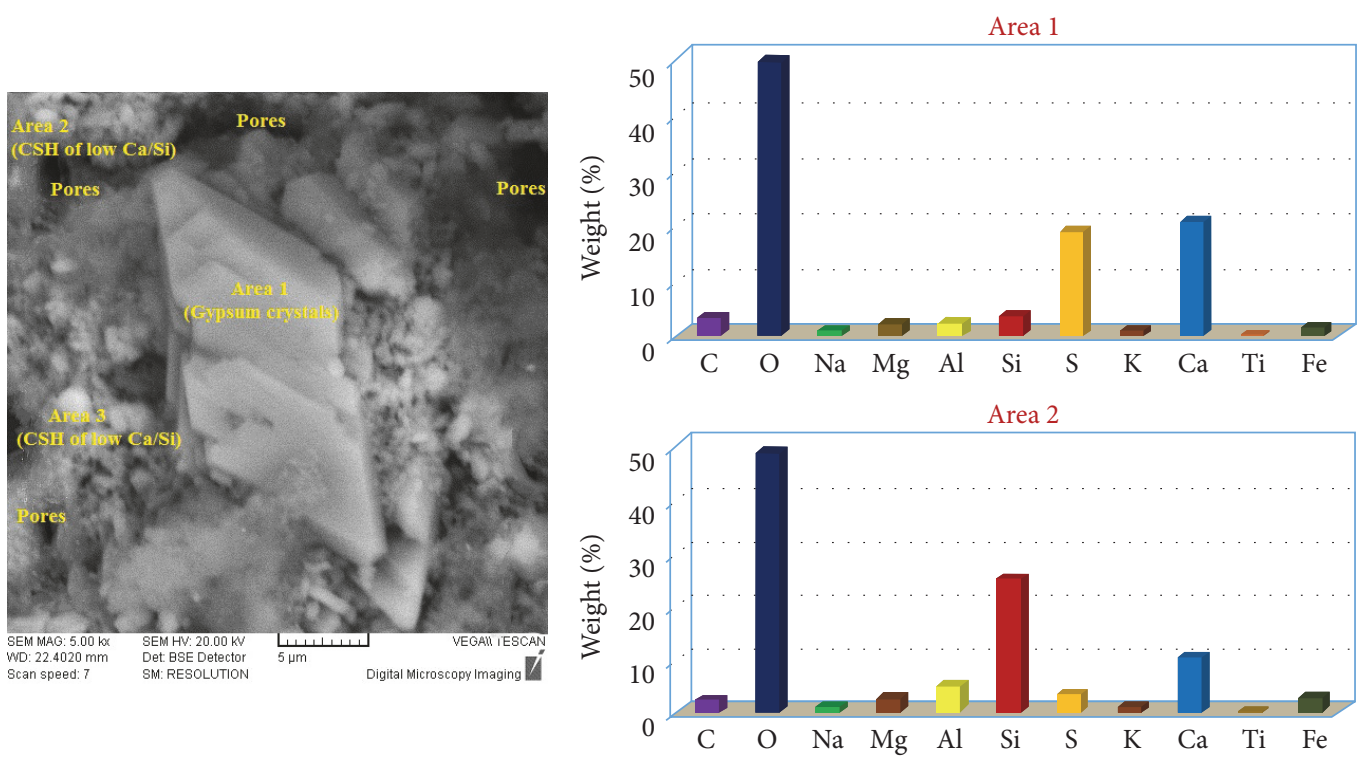

(a) SEM and EDX of VS0LF5-based mortar after 14 days of exposure to $5 \% \mathrm{H}_{2} \mathrm{SO}_{4}$
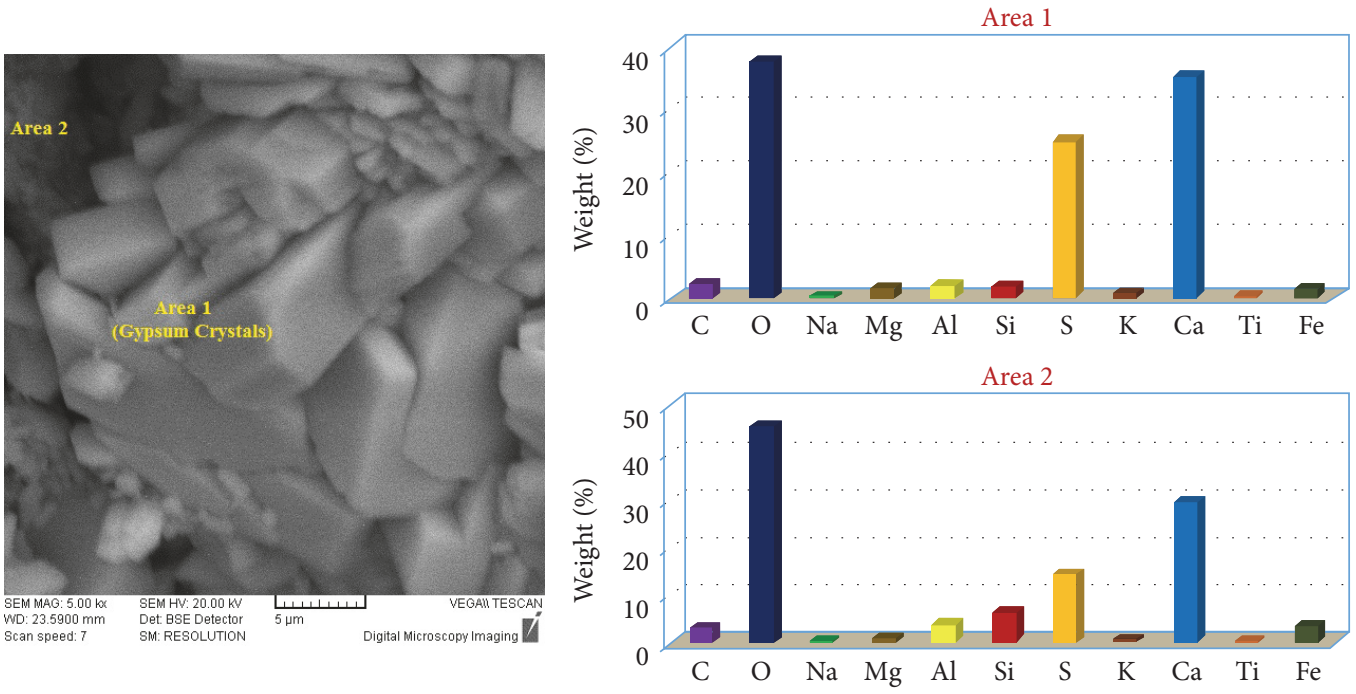

(b) SEM and EDX of VS30LF15-based mortar after 14 days of exposure to $5 \% \mathrm{H}_{2} \mathrm{SO}_{4}$

FIGURE 12: SEM and EDX of (a) VS0LF5-based mortar and (b) VS30LF15-based mortar after 14 days of exposure to $5 \% \mathrm{H}_{2} \mathrm{SO}_{4}$.

permeability than CEM I concrete. But in this research, it has been observed that, after 2-day curing, water penetration depth of $10 \%$ VS-based concrete was higher than that of CEM I. Increasing the moist-curing period of concrete from 28 to 90 days' reduced water penetration depths of all VS-based concrete. No concrete was found to be impermeable under aggressive conditions, before 28-day curing. The only mix that can be considered as impermeable under aggressive environments after 28-day curing, according to Neville [39], is VS30LF15-based concrete. However, all concrete containing VS contents $\geq 20 \%$ and $\mathrm{LF}$ contents $\geq 5 \%$ recorded water penetration depths less than $30 \mathrm{~mm}$. This can be attributed to the filling effect of limestone filler and the pozzolanic reaction of volcanic scoria.
3.6. Microstructure Observations of the Hydration Products. Fragments of VS0LF0-, VS30LF0-, VS0LF15-, and VS30LF15based paste specimens broken off and washed with acetone were examined and analyzed by SEM and EDX techniques. Figures 14, 15, 17, and 18 present the SEM photos and the EDX analysis of the studied pastes after 28 days' curing. The effect of adding limestone filler is clearly seen in modifying the microstructure of plain and VS-based pastes.

As shown in Figure 14, the SEM and EDX microanalysis of VS30LF0-based paste showed a very dense structure and indicated that the examined fractured sections mainly consist of $\mathrm{CSH}$ and $\mathrm{CASH}-\mathrm{ASH}$ phases with very low $\mathrm{CH}$ content which might be consumed through the pozzolanic reaction. Different phases, by contrast, were detected when adding $15 \%$ 


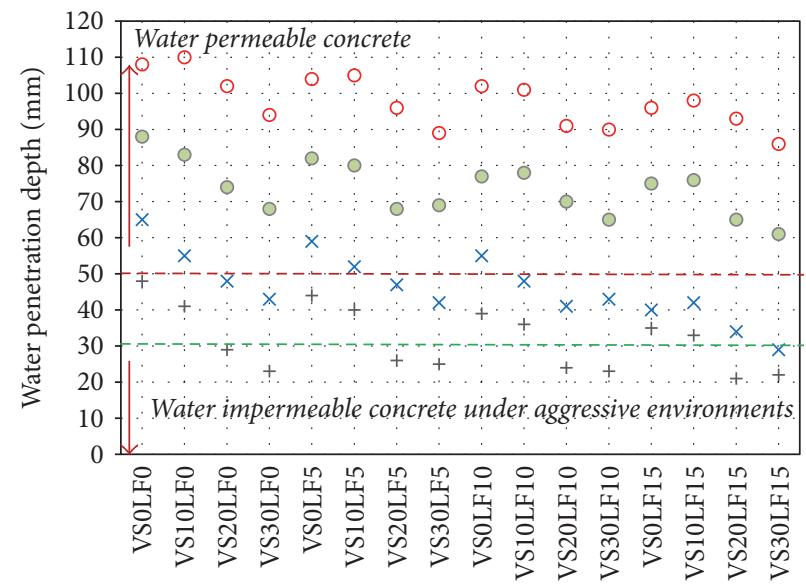

Concrete mixes

$$
\begin{array}{ll}
\circ 2 \text { days' curing } & \times 28 \text { days' curing } \\
\circ 7 \text { days' curing } & +90 \text { days' curing }
\end{array}
$$

FIGURE 13: Water penetration depths measured in different concrete mixes cured for 2, 7, 28, and 90 days.
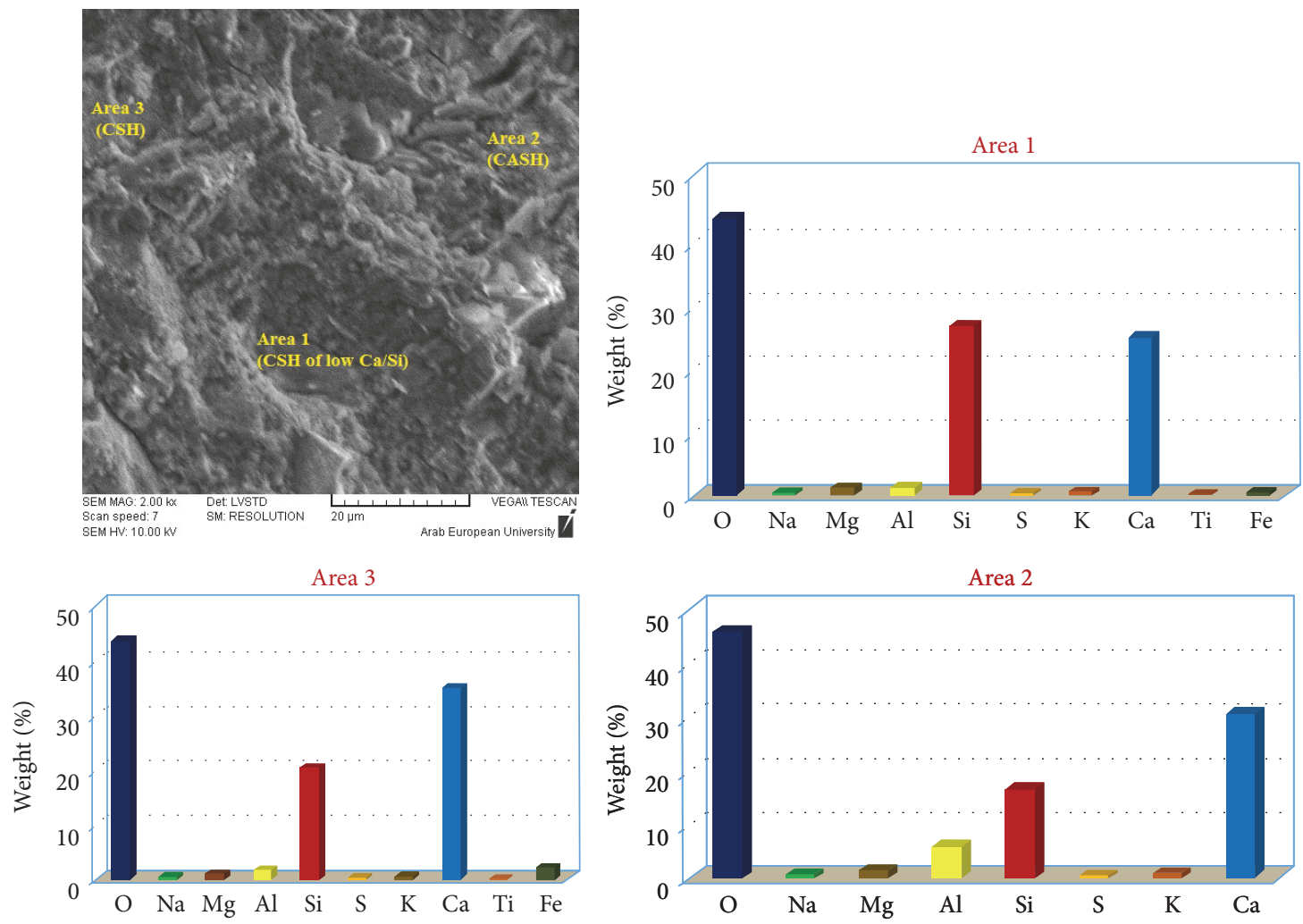

FIGURE 14: SEM and EDX analysis of 28 days' cured VS30LF0-based paste.

LF, as seen in Figure 15. EDX analysis of VS30-LF15-based paste showed major elements such as $\mathrm{Ca}, \mathrm{O}, \mathrm{Si}, \mathrm{C}$, and $\mathrm{Al}$ confirming the identification of carboaluminate hydrate and $\mathrm{CSH}$ formation. This, which was further confirmed by XRD analysis, as shown in Figure 16, is in agreement with the results reported in the literature $[9,31,51]$. Presence of LF could also fill the pores between the cement particles due to the formation of carboaluminate phases.
On the other hand, in Figure 17 a large number of needle-like crystals of ettringite in VS0LF15 can be seen. This confirms that limestone filler seems to stabilize ettringite as reported by other researchers $[9,11,13]$. This also confirms the role of limestone filler in chemically interacting with the aluminate phases in cement to stabilize a carboaluminate phase at the expense of monosulfoaluminate [13]. In addition, this action can increase the quantity of ettringite formed 

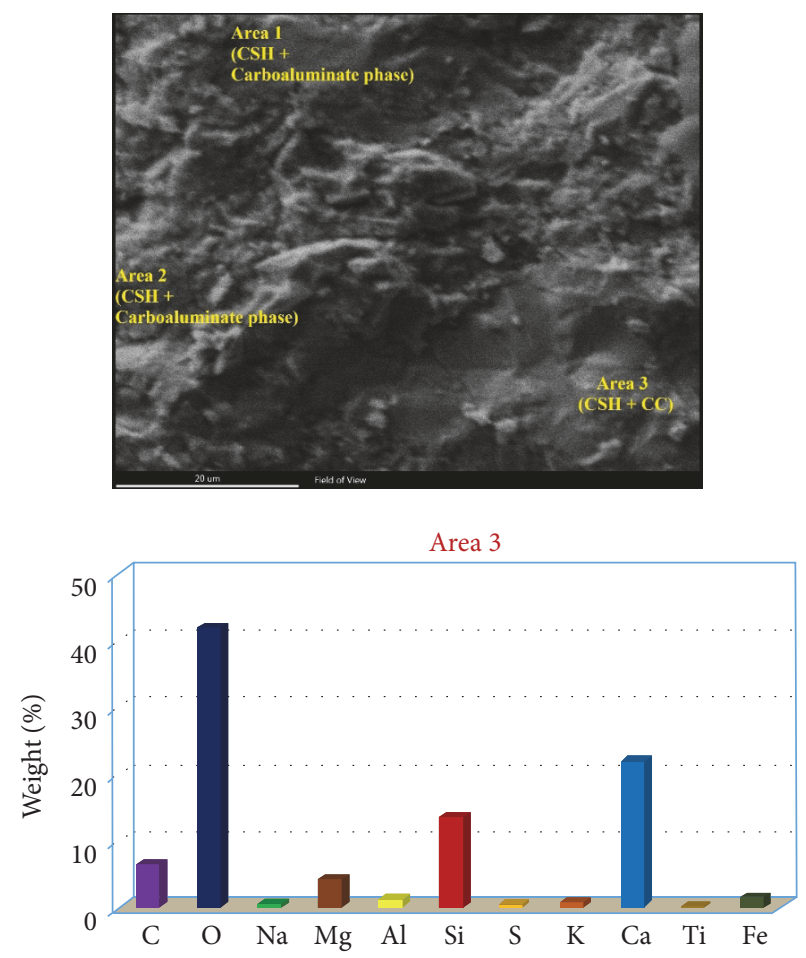

FIGURE 15: SEM and EDX analysis of 28 days' cured VS30LF15-based paste.

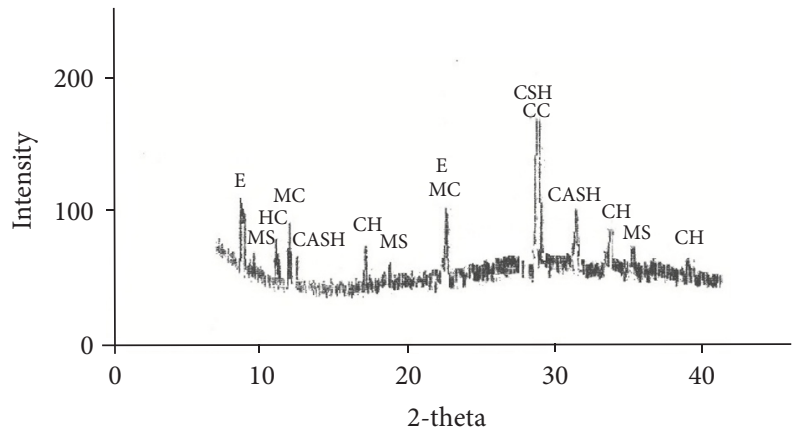

FIGURE 16: XRD of 28 days' cured VS30LF15-based paste (E: ettringite; MS: Monosulfate; HC: hemicarboaluminate; MC: monocarboaluminate; $\mathrm{CH}$ : calcium hydroxide; $\mathrm{CSH}$ : calcium silicate hydrates; $\mathrm{CASH}$ : calcium aluminate silicate hydrates; CC: calcium carbonate).

which leads to an increase in solid volume and thus decreased porosity and slightly improved mechanical strength [9]. Further, as clearly seen in Figure 18, darker areas were more frequent in case of VSOLF0-based paste, indicating its higher porosity when compared with the others.

\section{Conclusions}

From the experimental results, the following conclusions could be drawn:

(i) The compressive strength of mortar/concrete containing VS-based binders was lower than that of plain cement mortar at all ages. At early ages, the mortars containing $30 \%$
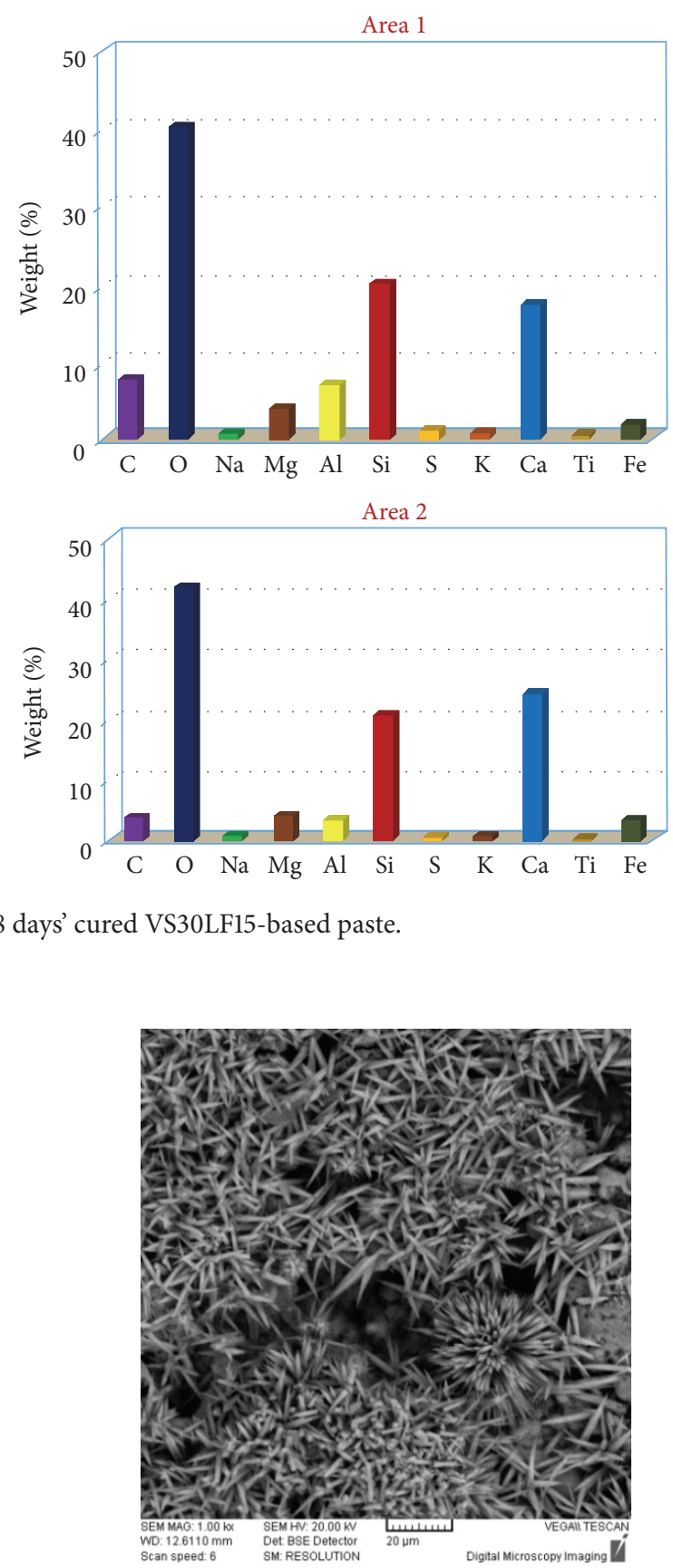

FIGURE 17: SEM of 28 days' cured VSOLF15-based paste.

VS had compressive strengths much lower than that of plain cement mortar. However, after 90 days' curing, the compressive strengths of VS-based mortars were comparable to those of plain cement mortar. Adding up to $10 \%$ LF content, by contrast, develops almost the same compressive strength as the corresponding plain cement.

(ii) The negative effect of VS on the early strength of mortars can be compensated by using LF, while the negative effect of LF on the compressive strength of mortars at later ages can be compensated by using VS. This positive synergy effectively counters the dilution effect on the strength performance of blended cements. So, it is expected that the future 


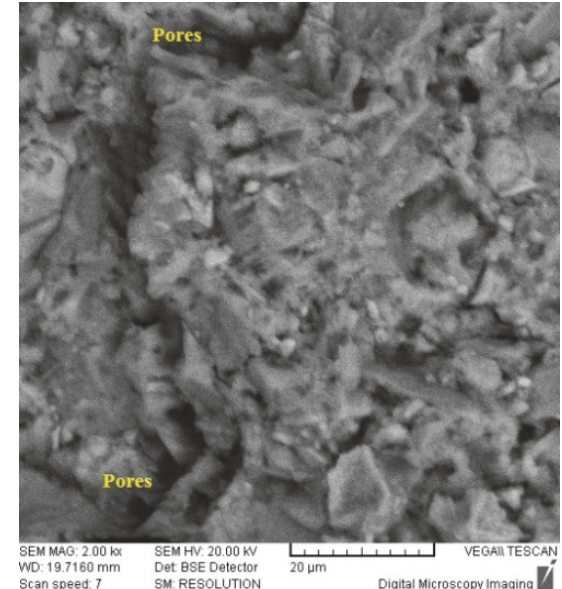

FIGURE 18: SEM of 28 days' cured VSOLF0-based paste.

world production and use of ternary blended cements will significantly be extended.

(iii) A strong correlation was observed between the compressive strength of concrete and that of mortars with a similar w/b ratio, such that one can be estimated from knowledge of the other.

(iv) Limestone filler is not solely an inert additive; $\mathrm{CaCO}_{3}$ reacts with aluminates to form carboaluminate phases. This has been confirmed by the results obtained and the microstructural analysis.

(v) Results of loss in weight after $\left(\mathrm{H}_{2} \mathrm{SO}_{4}\right)$ acidic exposure indicate generally superior performance of VS-based mortars and inferior performance of LF-based mortars compared to the respective control mortar. However, adding LF in a significant quantity $(15 \%)$ considerably improved sulfuric acid resistance of the mortars investigated.

(vi) Based on the results obtained, the authors derived an estimation equation of both compressive and flexural strength development incorporating the effects of VS and $\mathrm{LF}$ contents at a given curing time. The mechanical strength of mortar containing VS, LF, or both could be adequately predicted using (5). Development of such a good relationship between mechanical strengths and the supplementary cementing materials could be of considerable benefit. However, more parameters such as type and fineness of the materials used and w/b ratio should be taken into consideration.

(vii) Water permeability of VSLF-based concrete mixes was much lower than those of either plain concrete or VS-based concrete, especially at longer curing time and high replacement levels. This has also been confirmed by SEM/EDX analysis.

(viii) Use of ternary cements containing an adequate combination of limestone filler and volcanic scoria can lead to an efficient use of natural resources, saving energy consumption and reducing gaseous emissions without compromising the mechanical properties of cement. So, production of a green concrete could be promoted.

\section{Conflicts of Interest}

The authors declare no conflicts of interest.

\section{Acknowledgments}

The authors gratefully acknowledge the technical and financial support of this research from Damascus University. Thanks are also expressed to Eng. Amjad Bernieh (Lafarge Co.) and Professor Tamer al-Hajeh, Vice-President of AIU, for their appreciated help.

\section{References}

[1] A. M. al-Swaidani and S. D. Aliyan, "Effect of adding scoria as cement replacement on durability-related properties," International Journal of Concrete Structures and Materials, vol. 9, no. 2, pp. 241-254, 2015.

[2] N. Kouloumbi, G. Batis, and P. Pantazopoulou, "Efficiency of natural Greek pozzolan in chloride-induced corrosion of steel reinforcement," Cement, Concrete and Aggregates, vol. 17, no. 1, pp. 18-25, 1995.

[3] M. I. Khan and A. M. Alhozaimy, "Properties of natural pozzolan and its potential utilization in environmental friendly concrete," Canadian Journal of Civil Engineering, vol. 38, no. 1, pp. 71-78, 2011.

[4] M. R. Moufti, A. A. Sabtan, O. R. El-Mahdy, and W. M. Shehata, "Assessment of the industrial utilization of scoria materials in central Harrat Rahat, Saudi Arabia," Engineering Geology, vol. 57, no. 3-4, pp. 155-162, 2000.

[5] G. K. Al-Chaar, M. Alkadi, and P. G. Asteris, "Natural pozzolan as a partial substitute for cement in concrete," The Open Construction \& Building Technology Journal, vol. 7, pp. 33-42, 2013.

[6] Y. Senhadji, G. Escadeillas, H. Khelafi, M. Mouli, and A. S. Benosman, "Evaluation of natural pozzolan for use as supplementary cementitious material," European Journal of Environmental and Civil Engineering, vol. 16, no. 1, pp. 77-96, 2012.

[7] A. M. al-Swaidani, S. D. Aliyan, and N. Adarnaly, "Mechanical strength development of mortars containing volcanic scoriabased binders with different fineness," Engineering Science and Technology, an International Journal, vol. 19, no. 2, pp. 970-979, 2016.

[8] C. Shi, "An overview on the activation of reactivity of natural pozzolans," Canadian Journal of Civil Engineering, vol. 28, no. 5, pp. 778-786, 2001.

[9] K. De Weerdt, K. O. Kjellsen, E. Sellevold, and H. Justnes, "Synergy between fly ash and limestone powder in ternary cements," Cement and Concrete Composites, vol. 33, no. 1, pp. 30-38, 2011.

[10] V. Bonavetti, H. Donza, V. Rahhal, and E. Irassar, "Influence of initial curing on the properties of concrete containing limestone blended cement," Cement and Concrete Research, vol. 30, no. 5, pp. 703-708, 2000.

[11] V. L. Bonavetti, V. F. Rahhal, and E. F. Irassar, "Studies on the carboaluminate formation in limestone filler-blended cements," Cement and Concrete Research, vol. 31, no. 6, pp. 853-859, 2001.

[12] B. Lothenbach, G. Le Saout, E. Gallucci, and K. Scrivener, "Influence of limestone on the hydration of Portland cements," Cement and Concrete Research, vol. 38, no. 6, pp. 848-860, 2008.

[13] T. Matschei, B. Lothenbach, and F. P. Glasser, "The role of calcium carbonate in cement hydration," Cement and Concrete Research, vol. 37, no. 4, pp. 551-558, 2007.

[14] GEMGR, “"The General Establishment of Geology and Mineral Resources" in Syria (in Arabic)," Official document no. (3207/T/9), 2007. 
[15] GEMGR, ““"The General Establishment of Geology and Mineral Resources" in Syria (in Arabic)," A Guide for Mineral Resources in Syria, 2011.

[16] A. M. Al-Swaidani, "Prediction of compressive strength and some permeabilityrelated properties of concretes containing volcanic scoria as cement replacement," Revista Romana de Materiale/Romanian Journal of Materials, vol. 46, no. 4, pp. 505514, 2016.

[17] A. M. Al-Swaidani, S. D. ALiyan, and N. Adarnaly, "Production of more sustainable mortar using finer volcanic scoria-based blended cements," Journal of Sustainable Architecture and Civil Engineering, vol. 13, no. 4, pp. 49-61, 2015.

[18] Ş. Yetgin and A. Çavdar, "Study of effects of natural pozzolan on properties of cement mortars," Journal of Materials in Civil Engineering, vol. 18, no. 6, pp. 813-816, 2006.

[19] A. R. Pourkhorshidi, M. Najimi, T. Parhizkar, F. Jafarpour, and B. Hillemeier, "Applicability of the standard specifications of ASTM C618 for evaluation of natural pozzolans," Cement and Concrete Composites, vol. 32, no. 10, pp. 794-800, 2010.

[20] S. Tsivilis, E. Chaniotakis, E. Badogiannis, G. Pahoulas, and A. Ilias, "A study on the parameters affecting the properties of Portland limestone cements," Cement and Concrete Composites, vol. 21, no. 2, pp. 107-116, 1999.

[21] S. Sprung and E. Siebel, "Assessment of the suitability of limestone for producing Portland limestone cement," ZementKalk-Gips, vol. 44, no. 1, pp. 1-11, 1991.

[22] A. Çolak, "Characteristics of pastes from a Portland cement containing different amounts of natural pozzolan," Cement and Concrete Research, vol. 33, no. 4, pp. 585-593, 2003.

[23] S. Kenai, W. Soboyejo, and A. Soboyejo, "Some engineering properties of limestone concrete," Materials and Manufacturing Processes, vol. 19, no. 5, pp. 949-961, 2004.

[24] D. C. Montgomery and E. A. Peck, Introduction to Linear Regression Analysis, John Wiley \& Sons, New York, NY, USA, 1982.

[25] K. M. A. Hossain, "Blended cement using volcanic ash and pumice," Cement and Concrete Research, vol. 33, no. 10, pp. 16011605, 2003.

[26] K. Tosun, B. Felekoglu, B. Baradan, and I. A. Altun, "Portland limestone cement, Part 1-Preparation of cements," in Digest, pp. 1337-1355, 2009.

[27] V. Rahhal and R. Talero, "Early hydration of portland cement with crystalline mineral additions," Cement and Concrete Research, vol. 35, no. 7, pp. 1285-1291, 2005.

[28] G. Menéndez, V. Bonavetti, and E. F. Irassar, "Strength development of ternary blended cement with limestone filler and blastfurnace slag," Cement and Concrete Composites, vol. 25, no. 1, pp. 61-67, 2003.

[29] T. Vuk, V. Tinta, R. Gabrovšek, and V. Kaučič, "The effects of limestone addition, clinker type and fineness on properties of Portland cement," Cement and Concrete Research, vol. 31, no. 1, pp. 135-139, 2001.

[30] M. Schmidt, "Cement with interground additives capabilities and environmental relief, part 1," Zement Kalk-Gips, vol. 45, pp. 64-69, 1992.

[31] N. Voglis, G. Kakali, E. Chaniotakis, and S. Tsivilis, "Portlandlimestone cements. Their properties and hydration compared to those of other composite cements," Cement and Concrete Composites, vol. 27, no. 2, pp. 191-196, 2005.

[32] K. Celik, M. D. Jackson, M. Mancio et al., "High-volume natural volcanic pozzolan and limestone powder as partial replacements for portland cement in self-compacting and sustainable concrete," Cement and Concrete Composites, vol. 45, pp. 136-147, 2014.

[33] K. Githachuri and M. G. Alexander, "Durability performance potential and strength of blended Portland limestone cement concrete," Cement and Concrete Composites, vol. 39, pp. 115-121, 2013.

[34] D. P. Bentz, T. Sato, I. De La Varga, and W. J. Weiss, "Fine limestone additions to regulate setting in high volume fly ash mixtures," Cement and Concrete Composites, vol. 34, no. 1, pp. 11-17, 2012.

[35] M. F. Carrasco, G. Menéndez, V. Bonavetti, and E. F. Irassar, "Strength optimization of "tailor-made cement" with limestone filler and blast furnace slag," Cement and Concrete Research, vol. 35, no. 7, pp. 1324-1331, 2005.

[36] Y. A. Villagrán-Zaccardi, V. L. Taus, and Á. A. Di Maio, “Time evolution of chloride penetration in blended cement concrete," ACI Materials Journal, vol. 107, no. 6, pp. 593-601, 2010.

[37] K. Vance, M. Aguayo, T. Oey, G. Sant, and N. Neithalath, "Hydration and strength development in ternary portland cement blends containing limestone and fly ash or metakaolin," Cement and Concrete Composites, vol. 39, pp. 93-103, 2013.

[38] M. Ghrici, S. Kenai, and M. Said-Mansour, "Mechanical properties and durability of mortar and concrete containing natural pozzolana and limestone blended cements," Cement and Concrete Composites, vol. 29, no. 7, pp. 542-549, 2007.

[39] A. M. Neville, Properties of Concrete, Pearson Education, 5th edition, 2011.

[40] H. T. Cao, L. Bucea, A. Ray, and S. Yozghatlian, "The effect of cement composition and $\mathrm{pH}$ of environment on sulfate resistance of Portland cements and blended cements," Cement and Concrete Composites, vol. 19, no. 2, pp. 161-171, 1997.

[41] S. Aydin, H. Yazici, H. Yiǧiter, and B. Baradan, "Sulfuric acid resistance of high-volume fly ash concrete," Building and Environment, vol. 42, no. 2, pp. 717-721, 2007.

[42] E. Dan and I. Janotka, "Chemical resistance of Portland cement, blast- furnace slag Portland cement and sulphoaluminate-belite cement in acid, chloride and sulphate solution: Some preliminary results," Ceramics - Silikaty, vol. 47, no. 4, pp. 141-148, 2003.

[43] Y. Senhadji, G. Escadeillas, M. Mouli, H. Khelafi, and Benosman, "Influence of natural pozzolan, silica fume and limestone fine on strength, acid resistance and microstructure of mortar," Powder Technology, vol. 254, pp. 314-323, 2014.

[44] M. T. Bassuoni and M. L. Nehdi, "Resistance of self-consolidating concrete to sulfuric acid attack with consecutive $\mathrm{pH}$ reduction," Cement and Concrete Research, vol. 37, no. 7, pp. 10701084, 2007.

[45] M. T. Bassuoni, M. Nehdi, and M. Amin, "Self-compacting concrete: using limestone to resist sulfuric acid," Proceedings of the Institution of Civil Engineers - Construction Materials, vol. 160, no. 3, article 700030, pp. 113-123, 2007.

[46] Z. Makhloufi, E. H. Kadri, M. Bouhicha, and A. Benaissa, "Resistance of limestone mortars with quaternary binders to sulfuric acid solution," Construction and Building Materials, vol. 26, no. 1, pp. 497-504, 2012.

[47] S. H. Liu and Z. Wang, "Effect of limestone powder on acid attack characteristics of cement pastes," Medziagotyra, vol. 20, no. 4, pp. 503-508, 2014.

[48] F. Rendell and R. Jauberthie, "Deterioration of mortar in sulphate environments," Construction and Building Materials, vol. 13, no. 6, pp. 321-327, 1999. 
[49] V. Pavlík, "Effect of carbonates on the corrosion rate of cement mortars in nitric acid," Cement and Concrete Research, vol. 30, no. 3, pp. 481-489, 2000.

[50] E. F. Irassar, M. González, and V. Rahhal, "Sulphate resistance of type V cements with limestone filler and natural pozzolana," Cement and Concrete Composites, vol. 22, no. 5, pp. 361-368, 2000.

[51] M. Antoni, J. Rossen, F. Martirena, and K. Scrivener, "Cement substitution by a combination of metakaolin and limestone," Cement and Concrete Research, vol. 42, no. 12, pp. 1579-1589, 2012. 

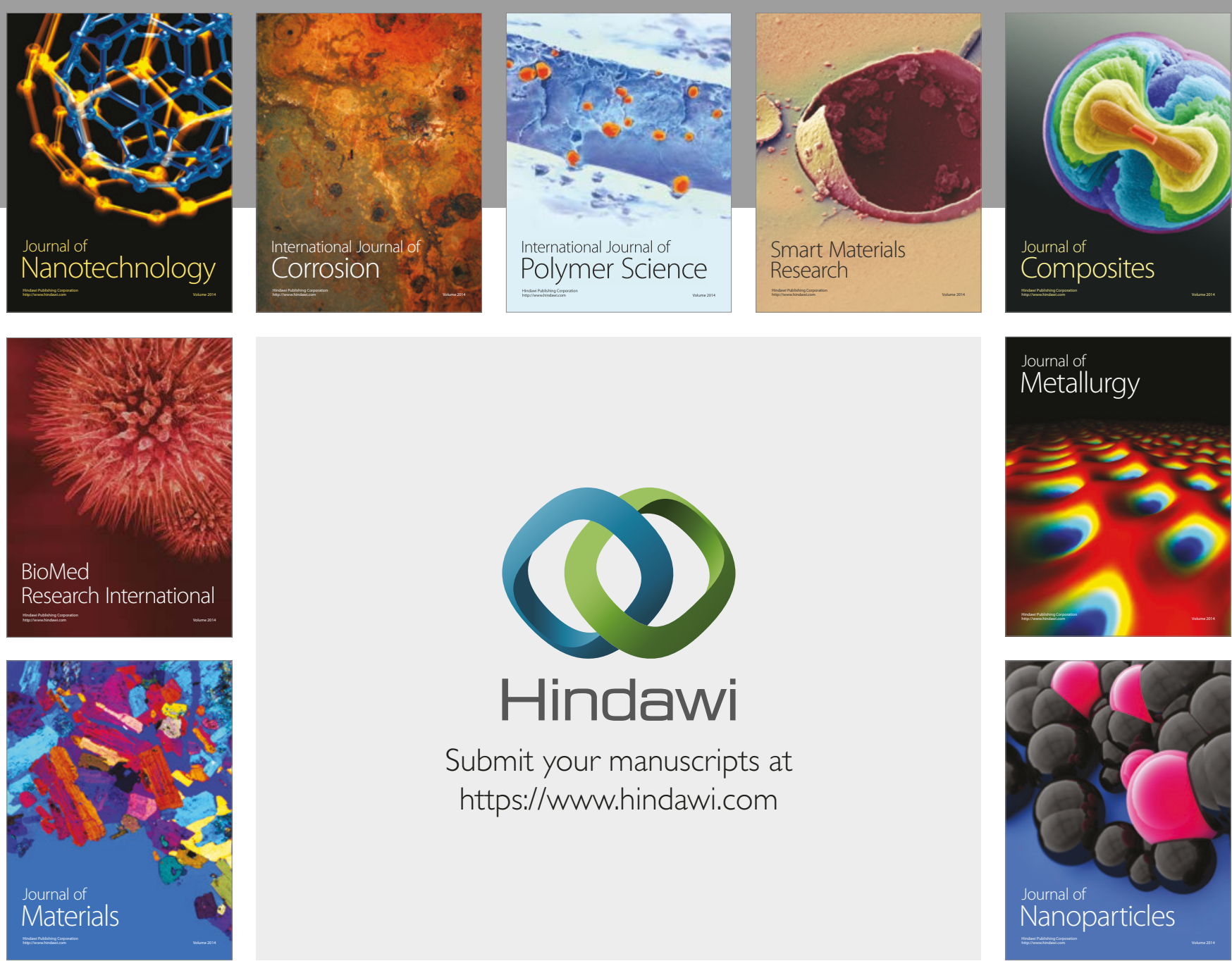

\section{Hindawi}

Submit your manuscripts at

https://www.hindawi.com
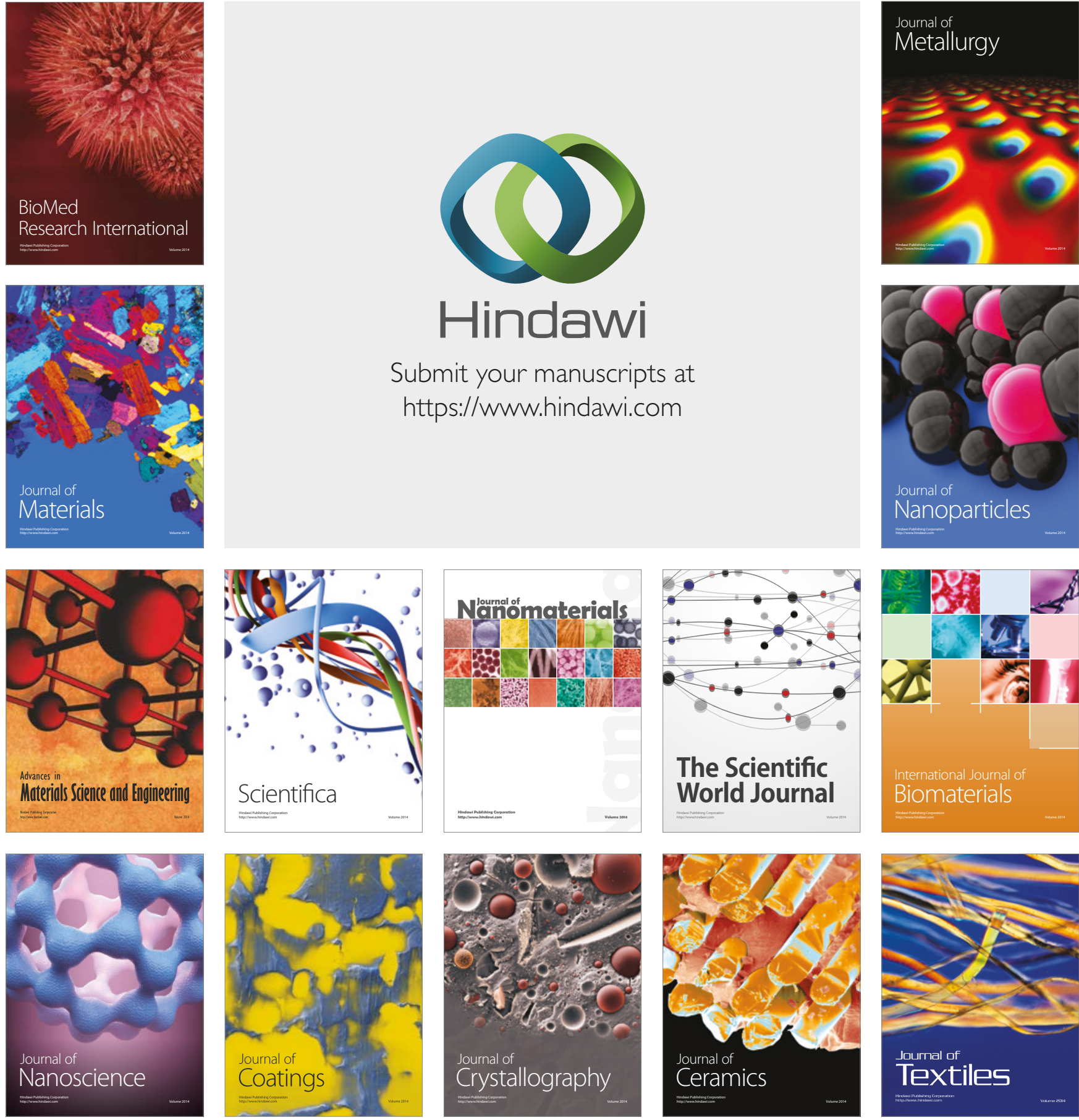

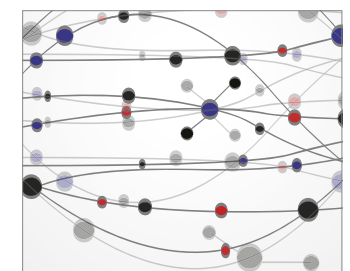

The Scientific World Journal
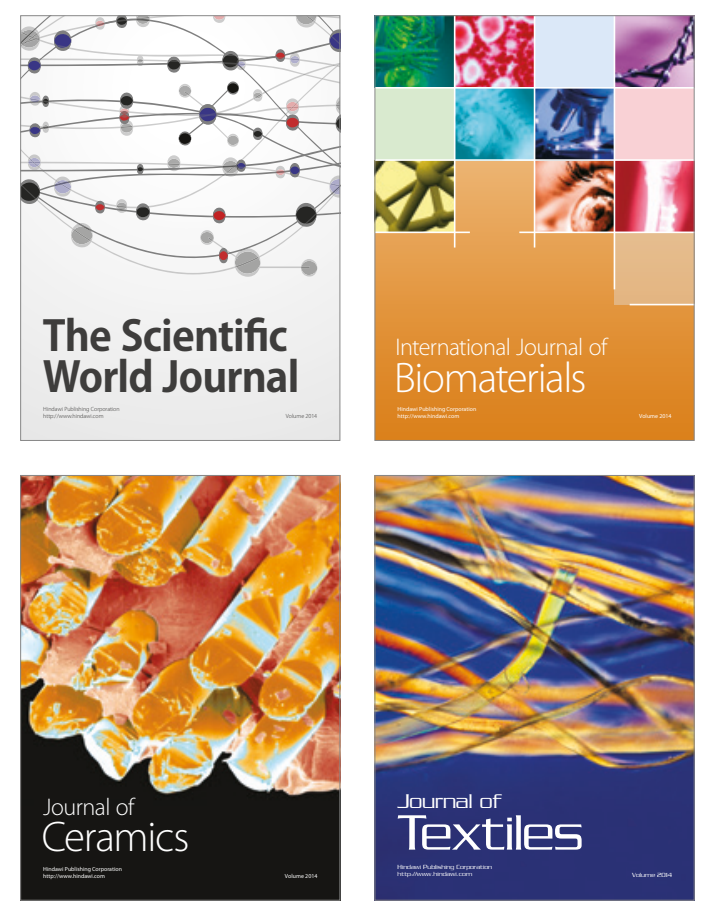